\title{
A DEMOCRACIA EFETIVADA ATRAVÉS DO PROCESSO CIVIL
}

\author{
Rennan Faria Thamay $^{1}$
}

\begin{abstract}
“LUTA. Teu dever é lutar pelo Direito.
Mas no dia em que encontrares o Direito em conflito com a Justiça, luta pela Justiça" (Eduardo Couture)
\end{abstract}

\begin{abstract}
RESUMO: Nossa sociedade, assim como as demais, busca freqüentemente a implantação da efetiva democracia, que foi apregoada na Carta Magna de 1988, sendo uma incessante pretensão dos cidadãos e juristas a obtenção de um resultado democrático.

O que se vê, veridicamente, em nosso país é que obtivemos uma democracia apenas escrita, que está taxada, mas que na prática nunca se fez presente, o que se torna uma grande frustração. Talvez em decorrência do Poder eleito como produtor dessa democracia, o Legislativo, que efetivamente nunca conseguiu esse desiderato.

Para que essa pretensa democracia se instale torna-se necessário que outro Poder seja o fiador dessa aplicação, aqui entra
\end{abstract}

\footnotetext{
${ }^{1}$ Advogado e sócio fundador do Krüger Advocacia, consultor jurídico e parecerista. É Especialista em Direito do Consumidor e Fundamentais pela UFRGS (Universidade Federal do Rio Grande do Sul). É Mestre em Direito Público pela UNISINOS (Universidade do Vale do Rio dos Sinos) e pela PUC Minas (Pontifícia Universidade Católica de Minas Gerais). É Doutorando em Direito pela UNLP (Universidad Nacional de La Plata) e pela PUC/RS (Pontifícia Universidade Católica do Rio Grande do Sul). Professor da graduação e do programa de pós-graduação (lato sensu) da PUC/RS. Professor titular e coordenador da Especialização em direito civil e processo civil no IMED/CETRA/RS. Professor titular da Especialização em direito do trabalho e previdenciário no IMED/CETRA/RS. Foi Professor titular de Direito Civil e Processual Civil do Retorno Jurídico/RS. Foi Professor titular do OABTUBE. Professor titular do CIUSP. Professor titular do Complexo EAD. Membro do IBDP (Instituto Brasileiro de Direito Processual). Membro Honorário da ABDPC (Academia Brasileira de Direito Processual Civil). Membro efetivo da comissão de acesso à justiça da $\mathrm{OAB} / \mathrm{RS}$. Membro efetivo do Grupo de Processos Coletivos da PUC/RS. Membro efetivo do Grupo de instrumentalidade do processo da PUC/ RS. Escritor da Revista de Processos Coletivos da PUC/RS, Revista Temas Atuais de Processo Civil e da RDS (Revista de Direito Social) com circulação nacional.
} 
o Judiciário por ser um Poder, até mesmo, menos parcial. Esse Poder poderá conseguir a tão sonhada implantação da democracia, mas para isso dependerá de um meio eficaz, idôneo e participativo, do qual chamamos de Processo.

É através do Processo Civil que poderemos efetivar a implementação da democracia através da participação do cidadão através do Processo, que chegará as mãos do Judiciário podendo dar guarida à dita implementação, através do seu critério de retidão e de seriedade, características que são naturais a esse Poder que mereceu, merece e merecerá sempre o respeito de nossos cidadãos e juristas.

Palavras-chave: Democracia, Judiciário e democracia, Processo Civil e democracia.

\section{INTRODUÇÃO}

Nossa sociedade imediatista caminha a passos largos para um futuro do qual não se sabe onde desaguar, nosso país se desenvolveu muito rápido, em relação a países como os europeus que demoraram muito mais para chegarem ao patamar atual de desenvolvimento, e esse desenvolvimento célere para um país relativamente "jovem" como o nosso pode trazer conseqüências perigosas.

Todo esse crescimento é interessante, principalmente por trazer novas perspectivas para as pessoas que vivem o presente, rememorando o passado de lutas e de vitórias que propiciarão um futuro belo, que promete muitas conquistas e vitórias ${ }^{2}$. Para tudo isso, passaremos pela análise a incessante perseguição à democracia, busca que se dá, para nossa sociedade, já de delongado período.

Assim, será analisada a importância da democracia e como superarmos o estágio atual de "pseudo" democracia que, a bem da verdade, nada tem a ver com a real noção da democracia, sendo qualquer outra "coisa" menos democracia.

\footnotetext{
${ }^{2}$ Essa análise a partir de um passado iluminado é relevante para que o futuro seja influenciado por um passado vitorioso e belo, isso é relevante para que a nossa sociedade não ande em um futuro nebuloso, fazendo vívidas as palavras do douto jurista Frances Tocqueville - que foi magistrado em 1827 -, que o passado, quando não mais ilumina o futuro, deixa o espírito andando nas trevas. In: TOCQUEVILLE, Alexis de. La démocratie em Amérique, Paris: Garnier: Flammarion, 1951, t. II, cap. VIII, p. 336.
} 
Nessa labuta observaremos que para chegar a uma verdadeira aplicação da democracia será necessária uma nova forma de agir, entregando o dever de fazer democracia ao Poder que esteja mais capacitado para tal desiderato. Este Poder é, sem duvida alguma, o Judiciário, que a partir de suas peculiaridades pode ser um poder imparcial e que através do processo poderá efetivar a participação democrática dos cidadãos.

Veridicamente observar-se-á que o Judiciário só terá condições de cumprir a noção de democracia se utilizar o processo para esse fim, sendo o processo o "meio" adequado às manifestações de todos os cidadãos, superando a velha noção de que democracia se constrói através da votação e que seja esse o momento mais elevado da democracia. Sabe-se que esse momento pode representar certa manifestação democrática, mas não em seu escopo mais poderoso, até porque ocorre esporadicamente e por vezes os votos são negociados o que nada tem a ver com o conceito de democracia que foi introduzido em várias das nações.

Para que seja implantada realmente a democracia, e ela sai do papel para as ruas, faz-se necessário entregar ao Judiciário, através do processo, o poder de tornar a nossa sociedade realmente democrática.

\section{A DEMOCRACIA: ASPECTOS RELEVANTES}

A sociedade brasileira que muito mudou desde a sua formação, passa hoje por um momento bem distinto dos demais já vividos, um momento em que se busca negociações complexas e massificadas, pretendendo, ademais, solucionar os conflitos e resolver as coisas, passando por uma condição de imediatismo e não mais a celeridade ${ }^{3}$.

Esse acelerado caminho que nossa sociedade vivencia hoje é natural ao ritmo que seguimos, que é muito acelerado em comparação com ostros países que demoraram muito mais para chegar a um

\footnotetext{
${ }^{3}$ Deve-se tomar o devido cuidado para que as coisas não se acelerem por demais, visto que o direito deve seguir o seu tempo normal, sem uma aceleração exacerbada e desmotivada que prejudicaria e muito a natural preservação de um direito em sua essência máxima. (OST, François. O tempo do direito. Lisboa: Instituto Piaget, 1999, p. 39.)
}

RPGE, Porto Alegre, v. 33, n. 70, p. 87-124, 2012 


\section{0}

estágio como o de nosso país, visto que não mais nos encontramos na modernidade, mas, sim, na pós-modernidade ${ }^{4}$.

Essa ocorrência é natural para um país que cresceu e se desenvolveu muito rápido, superando, em proporção de crescimento pelo tempo de existência, os países da Europa ou outros de outro continente.

A constante busca de celeridade ${ }^{5}$ não é, em sua natureza, ruim, e sim interessante, mas se observada de forma incorreta pode acarretar problemáticas grandiosas e, por vezes, até macular direitos que deveriam ser observados com o devido passar do tempo e transcurso de uma demanda6.

\footnotetext{
${ }^{4}$ Nesse sentido ver os seguintes autores: JAYME, Erik. Cours général de droit intenacional prive, In recueil des cours, Académie de droit intenacional, t, 251, 1997, p. 36-37; MARQUES, Claudia Lima. Contratos no código de defesa do consumidor: o novo regime das relações contratuais, 4. ed. rev., atual. e ampli., incluindo mais de 1.000 decisões jurisprudenciais. São Paulo, RT, 2002, p.155-175. LYOTARD, Jean-François. O pós-moderno, Rio de Janeiro: Olympio Editora, 1986. KUMAR, Krishan. Da sociedade pós-industrial à pós-moderna, Rio de Janiro: Jorge Zahar Editor, 1997. HARVEY, David. Condição pós-moderna, São Palo: Edições Loyola, 1992. DELACAMPAGNE, C. História da Filosofia no Século XX, Rio de Janeiro: Jorge Zahar Editor, 1995. VATTIMO, Gianni. O Fim da Modernidade: niilismo e hermenêutica na cultura pós-moderna, Lisboa: Editorial Presença, 1987. FEATHERSTONE. Cultura de consumo e Pós-modernismo, São Paulo: Studio Nobel, SESC, 1995. GIDDENS. "A vida em uma sociedade pós-tradicional", In: BECK, GIDDENS \& LASH, 1997. CAMPBELL, C. The Romantic Ethic and the Spirit of Modern Consumerism, Oxford: Blackwell,1987. SANTOS, Boaventura de Souza. Pela Mão de Alice: O social e o político na pós-modernidade, São Paulo: Cortez, 1997. BAUMAN, Zygmunt. Modernidade e Ambivalência, Rio de Janiro: Jorge Zahar Editor, 1999. ROUANET, S. P. As razões do iluminismo, São Paulo: Companhia das Letras, 1987.

${ }^{5}$ Deve-se guardar a Idéia de processo célere, para que possa dentro de um prazo razoável atingir os fins para os quais a ação foi proposta. Rememore-se que segundo o jurista Rui Portanova o princípio da celeridade é derivado do da economia processual. In: PORTANOVA, Rui. Princípios do processo civil, $6^{\circ}$ ed., Porto Alegre: Livraria do Advogado, 2005, p. 171 e ss.

${ }^{6} \mathrm{O}$ emprego da celeridade deve se dar com a devida moderação, visando não prejudicar o direito efetivamente constituído e pelo qual se instala o litígio judicial, pois nem sempre a decisão rápida terá o condão de ser adequada ou ainda correta. Assim, a celeridade, por mais importante que seja, tem limites que devem ser observados. In: SANTOS, Boaventura de Souza. Para uma revolução democrática da justiça, $2^{\circ}$ ed., São Paulo: Cortez, 2008, p. 27.
} 
Assim, a sociedade de nosso país chegou a um ponto que parece irreversível, até porque muitas das mudanças que vieram com a celeridade são positivas, mas outras das alterações são prejudiciais ao extremo como se perceberá quando da análise da questio.

Com o Processo Civil brasileiro as mudanças foram muitas e muito intensas, causando, por vezes, satisfação para alguns dos processualistas que utilizam as regras processuais diariamente, não sendo satisfatórias, tais mudanças, para outros, tudo passa a depender do olhar que se terá frente às alterações ${ }^{7}$.

Nesse sentido assim como a sociedade brasileira mudou muito rápido, até o próprio Direito Processual Civil mudou, de forma acelerada e muito precoce, adotando outros critérios e linhas de atuação, visando, desde então, a eficiência e a celeridade na solução da lide ${ }^{8}$.

Essas mudanças aplicadas ao direito - especificamente ao Processo Civil - são derivadas das mudanças que a própria sociedade acaba por passar, sendo essas cada vez mais naturais em decorrência do crescimento que o ser humano experimenta da cada dia, o que é uma natural ocorrência.

Com todas essas mudanças que hoje observamos outra tantas se fazem necessárias para que o Processo Civil, como ciência para alguns como Ovídio A. Baptista da Silva ${ }^{9}$, venha a ser um sistema ${ }^{10}$ melhor e adaptado as novas realidades e direitos ${ }^{11}$.

${ }^{7}$ Desde 1973 o Código de Processo Civil mudou muito, passando a observar as questões da lide a partir de uma visão mais célere e voltada ao respeito das garantias constitucionais do processo, o que é efetivamente muito interessante e positivo. In: DELGADO, José Augusto. As garantias do cidadão na justiça, coord. Sálvio de Figueiredo Teixeira, São Paulo: Saraiva, 1993, p.65 e ss.

${ }^{8}$ Neste sentido vide: BUENO, Cassio Scarpinella. Curso sistematizado de direito processual civil: teoria geral do direito processual civil: vol. 1, São Paulo: Saraiva, 2007, p. 79-80.

9 SILVA, Ovído A. Baptista da. Participação e processo coord. Ada Pellegrini Grinover, São Paulo: RT, 1988, p. 101.

${ }^{10}$ Quando se fala de sistema se está sempre a rememorar as idéias apregoadas por Niklas Luhmann, quando defende a idéia de uma teoria sistêmica do direito, chegando a uma conclusão de que o sistema jurídico se auto-reproduz, sendo isso a autopoiese. Esse processo que se renova sendo capaz de auto-reprodução foi abordado pelo autor LUHMANN, Niklas. Sitemi sociali: Fondamenti di una teoria generale, Bolonha:Il Mulino, 1990, p. 64.

11 Deve-se buscar desde logo a efetividade dos direitos, levando-os a sério, concretizando-os e fazendo com que a sociedade possa se tranqüilizar no sentido de 
Um exemplo das mudanças é a própria existência do art. 285A do Código de Processo Civil ${ }^{12}$, que instaurou a possibilidade de o magistrado emanar liminarmente a sentença ${ }^{13}$, independentemente de citação da parte adversa, desde que já tenha se manifestado em caso análogo julgando esse improcedente, sendo, por critérios de celeridade, aplicada a mesma sentença de total improcedência para as futuras demandas que venham a serem propostas.

É em meio a todas essas mudanças que nos encontramos, vivendo uma suposta democracia ${ }^{14}$ que, efetivamente, não existe, visto que não passa de uma democracia ${ }^{15}$ plantada em mera folha de papel, ou seja, legalmente falando, pois a nossa Carta Magna

que seus direitos estão sendo bem cuidados e prestigiados. Nesse sentido de levar os direitos a sério deve ser observado DWORKIN, Ronald. Levando os direitos a sério, trad. Nelson Boeira, São Paulo: Martins Fontes, 2002, p. 283 e ss. Também vejamos SANTOS, Boaventura de Souza. Para uma revolução democrática da justiça, $2^{\circ}$ ed., São Paulo: Cortez, 2008, p. 30.

${ }_{12}$ Esse dispositivo foi inserido no sistema processual atual pela Lei 11.277 de 07/02/2006, que entrou em vigor 90 dias após a publicação que se deu em 08/02/2006.

${ }^{13}$ Sobre aquilo que hoje surge como "jurisprudencialismo" dotando à jurisprudência maior relevância do que a própria norma, ver PICORDI, Nicola. La vocazione del nostro tempo per la giurisdizione, revista trimestral de Diritto Procedura Civile, Giuffrè, 2004.

${ }^{14}$ Um livro muito interessante sobre a democracia foi escrito pela professora da UFSC Maria Lúcia Duriguetto, in: DURIGUETTO, Maria Lúcia. Sociedade civil e democracia - Um debate necessário. São Paulo: Cortez, 2007.

${ }^{15}$ Sobre a idéia de democracia devemos observar artigo construído pelo saudoso jurista Ovídio A. Baptista da Silva in: SILVA, Ovídio A. Baptista da. Democracia e sociedade de massa - www.Baptistadasilva.com.br/artigos. verbis: "Mesmos os liberais que ainda acreditam que seja possível alcançar o mundo melhor sonhado pelas idéias da modernidade, não escondem que, apesar da retórica, dirigimo-nos, cada vez menos na direção do povo. Giovanni Sartori nô-lo confirma, ao escrever: "Hoje em dia, não obstante a retórica em contrário, nos movemos na direção de cada vez menos poder do povo. A causa óbvia disto é que um máximo de poder popular só é possivel em sociedades simples nas quais as funções de direção sejam relativamente elementares. A maior complexidade, interconexão e a magnitude gigantesca dos mecanismos da vida social e econômica determinam que a opinião dos especialistas adquira um peso específico superior a seu voto como eleitor" . 
refere que nosso país é um Estado Democrático de Direito ${ }^{16}$, que de democracia pouco realmente existe.

Não estamos contra a idéia de um Estado Democrático, até porque esse Estado, se realmente implantado, tornar-se-ia muito benéfico para todos os membros de nossa sociedade, o que claramente não se dá em nossos dias, sendo, essa ocorrência, mais uma demonstração de que a democracia apregoada está somente posta na letra da Lei ${ }^{17}$, que se não aplicada e realizada no mundo fenomênico não passará de ilusão e mero sonho.

A democracia ${ }^{18}$ deveria sim ser implantada, pois faria com que os cidadãos pudessem participar mais, fazendo com que o país seguisse, realmente, a linha que o povo definisse, já que todo o poder

\footnotetext{
${ }^{16}$ Essa referência se dá tanto no preâmbulo da Constituição Federal como também no artigo $1^{\circ}$. Assim vejamos o preâmbulo, vide: "Nós, representantes do povo brasileiro, reunidos em Assembléia Nacional Constituinte para instituir um Estado Democrático, destinado a assegurar o exercício dos direitos sociais e individuais, a liberdade, a segurança, o bem-estar, o desenvolvimento, a igualdade e a justiça como valores supremos de uma sociedade fraterna, pluralista e sem preconceitos, fundada na harmonia social e comprometida, na ordem interna $e$ internacional, com a solução pacífica das controvérsias, promulgamos, sob a proteção de Deus, a seguinte CONSTITUIÇÃO DA REPÚBLICA FEDERATIVA DO BRASIL." Também vejamos o art. $1^{\circ}$ : "Art. $1^{\circ} \mathrm{A}$ República Federativa do Brasil, formada pela união indissolúvel dos Estados e Municípios e do Distrito Federal, constitui-se em Estado democrático de direito e tem como fundamentos:"

${ }^{17}$ Ovídio aduz que como dizia Pontes nós brasileiros, especializamo-nos em produzir leis cada vez mais numerosas, sem a mínima intenção de cumpri-las. O douto processualista ainda continua referindo que seria ideal se os juristas pretendessem novos espaços de participação democrática, deixando de se limitarem a buscar novos códigos, ou que se aditassem mais leis, particularmente o processo civil (SILVA, Ovído A. Baptista da. Participação e processo coord. Ada Pellegrini Grinover, São Paulo: RT, 1988, p. 110-111.)

18 Norberto Bobbio relembras as menções feitas por Karl Poppes no sentido de que o regime democrático é o único que permite aos cidadãos se livrarem de seus governantes por formas pacíficas e sem derramamento de sangue. Tudo isso demonstra o grau de participatividade e força que a democracia devidamente implantada poderia ter. (BOBBIO, Norberto. O futuro da democracia: uma defesa das regras do jogo, $2^{\circ}$ ed., da trad. bras., p.39.)
} 
emana do povo que é representado por seus eleitos, os políticos ${ }^{19}$, não se tratando de questão meramente política ${ }^{20}$.

Nisso vemos enormes problemas, pois aquilo que deveria ser, através dos políticos ${ }^{21}$, a manifestação do povo, " a voz do povo", efetivamente, não é, acabando por ser a reprodução da vontade interna de cada um dos parlamentares, que utilizam os poderes que lhes foram atribuídos pelo povo, para agirem em seu favor, utilizando para benefício próprio, o que nos põe nessa situação problemática em que nossa sociedade se encontra ${ }^{22}$.

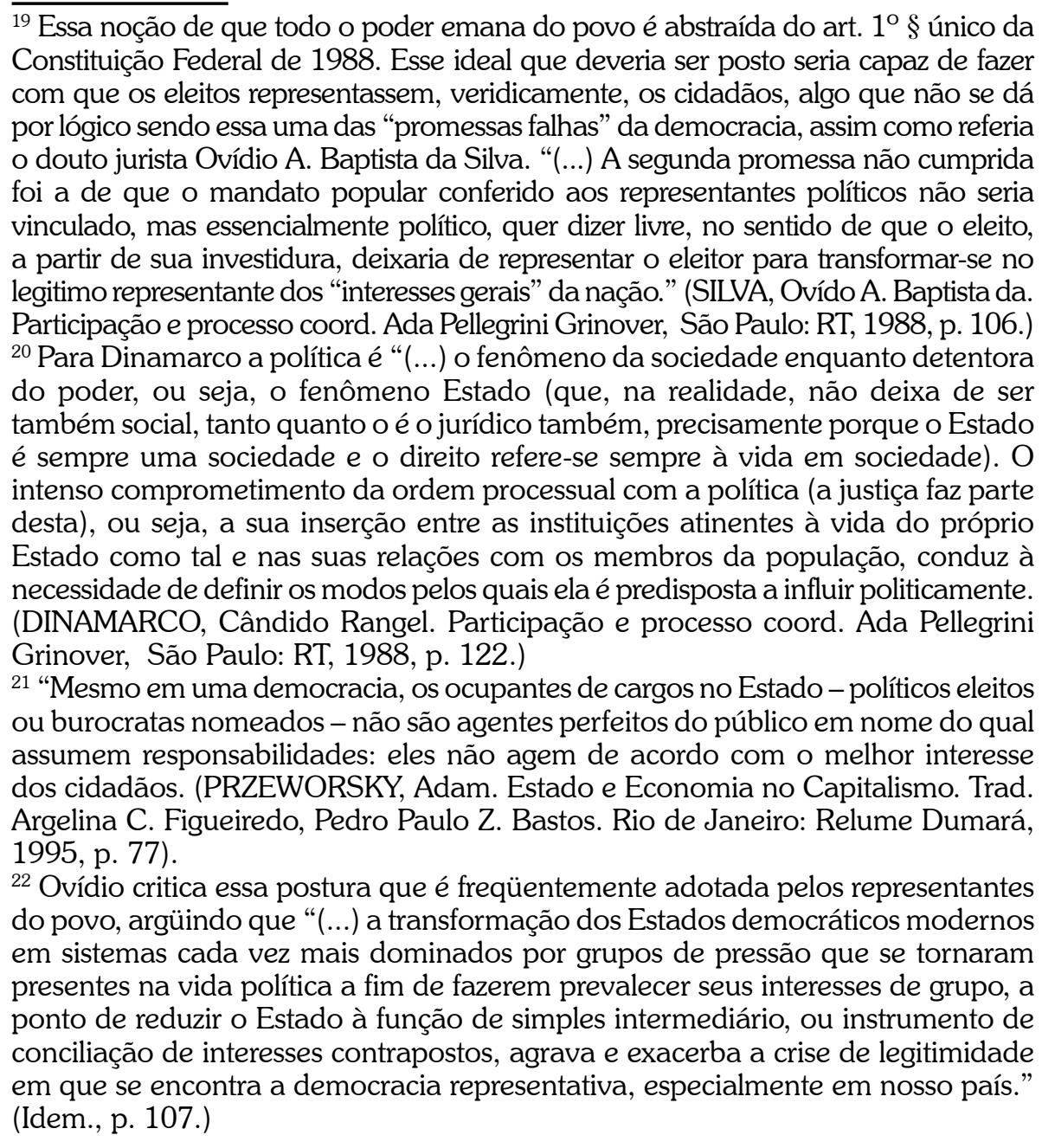


Em meio a toda essa problemática, poucas são as possibilidades que, veridicamente, o povo detém para exercer a democracia, participando de algo, diga-se como exemplo os plebiscitos ${ }^{23}$ ou ainda os referendos ${ }^{24}$ que chamam o povo para que deliberem sobre determinadas questões que sejam de interesse nacional e dos próprios cidadãos.

Aparentemente a participação popular se encerra, a priori, com as eleições ${ }^{25}$ onde após a escolha dos representantes os ci-

\begin{abstract}
${ }^{23}$ Sobre esse conceito vale observar as lições do Constitucionalista José Afonso da Silva aduzindo que plebiscito é também uma consulta popular, semelhante ao referendo; difere deste no fato de que visa a decidir previamente uma questão política ou institucional, através de sua formulação legislativa, ao passo que o referendo versa sobre a aprovação de textos de projeto de lei ou de emenda constitucional, já aprovados; o referendo ratifica (confirma) ou rejeita o projeto aprovado; o plebiscito autoriza a formulação da medida requerida(...) (SILVA, José Afonso da. Curso de Direito Constitucional Positivo, $15^{\circ}$ ed., rev. e atual., São Paulo: Malheiros, 1998, p. 146). Canotilho ainda refere que o plebiscito se dá como a pronuncia popular sobre escolhas ou decisões políticas - i.e., confiança num chefe político ou opção por uma ou outra forma de governo (CANOTILHO, José Joaquim Gomes. Direito Constitucional e Teoria da Constituição, $7^{\circ}$, ed., Coimbra: Almedina, 2003, p. 296).

${ }^{24}$ Nas Palavras do Constitucionalista brasileiro José Afondo da Silva o referendo popular que se caracteriza no fato de que projetos de lei aprovados pelo legislativo devam ser submetidos à vontade popular, atendidas certas exigências, tais como pedido de certo número de eleitores, de certo número de parlamentares ou do próprio chefe do executivo, de sorte que o projeto se terá por aprovado apenas se receber votação favorável do corpo eleitoral, do contrário, reputar-se-á rejeitado (SILVA, José Afonso da. Curso de Direito Constitucional Positivo, $15^{\circ}$ ed., rev., e atual., São Paulo: Malheiros, 1998, p. 143). Por sua vez Canotilho define referendo como a consulta feita aos eleitores sobre uma questão ou texto através de um procedimento formal regulado em lei CANOTILHO, José Joaquim Gomes. Direito Constitucional e Teoria da Constituição, $7^{\circ}$, ed., Coimbra: Almedina, 2003, p. 295.) ${ }^{25}$ Observando o critério das eleições não como efetiva participação popular mais como forma singela de eleger os representantes da população, que verdadeiramente não reproduz democracia temos as observações de PRZEWORSKY, Adam. Estado e Economia no Capitalismo, trad. Argelina C. Figueiredo, Pedro Paulo Z. Bastos. Rio de Janeiro: Relume Dumará, 1995, p. 24: "Riker [1982] argumentou que os teoremas da impossibilidade invalidaram a interpretação das eleições como uma expressão da vontade popular, sugerindo que deveríamos pensar as eleições como uma oportunidade negativa de eliminar dirigentes indesejáveis. Uma vez que as eleições não são um mecanismo significativo para a expressão da vontade popular, não podem ser vistas como outorgando aos governos um mandato para perseguir quaisquer políticas particulares".
\end{abstract}

RPGE, Porto Alegre, v. 33, n. 70, p. 87-124, 2012 


\section{6}

dadãos acabam esquecidos, até que venha, por mais uma vez, as próximas eleições, onde novamente o cidadão é importante para a "democracia" 26 pois vota e ali põe toda a sua força participativa.

Realmente a democracia ${ }^{27}$, que tanto se busca, por vezes através do Legislativo é complexa de ser realmente implantada e praticada, talvez pela forma em que a participação popular se dá, somente em momentos de eleições.

No poder Executivo a situação é similar, guardando suas peculiaridades, mas que em nada de novo se apresenta.

Outra vida de busca da aplicação real da democracia ${ }^{28}$ seria através do Poder Judiciário - utilizando-se do processo -, onde, tanto a priori quanto a posteriori, há maior participação dos cidadãos, que se utilizam do processo para chegar a participar da construção

${ }^{26}$ Deveria a Democracia buscar a efetivação da vontade geral dos cidadãos, que poderia ser garantida através da manifestação dos elegidos que seriam os representantes da nação. Assim refere o jurista Ovídio A. Baptista da Silva que " (...)a partir dessa incapacidade demonstrada pelos regimes democráticos para a formação da sonhada "vontade geral" e da persistência das oligarquias e de seus interesses, que a prática política tornaram transparentes e inocultáveis, é que a crise de legitimidade do sistema representativo mais se exacerba e torna-se visível. (SILVA, Ovído A. Baptista da. Participação e processo coord. Ada Pellegrini Grinover, São Paulo: RT, 1988, p. 108.)

${ }^{27} \mathrm{Na}$ noção de democracia podemos encontrar segundo Canotilho a forma direita e semi-direta, vide: "O exercício do poder directamente pelo povo - democracia directa - pressupõe uma estrutura territorial e social praticamente inexistente na época actual. O arquétipo dos Town Meetings americanos ou dos Landsgemeine suiços desapareceu quase por completo nas democracias constitucionais complexas (cfr. entre nós, art. $245^{\circ} / 2$ da CRP, que prevê o 'plenário de cidadãos eleitores'). Não desapareceram, porém, os mecanismos político-constitucionais de democracia semi-directa, progressivamente presentes nas constituições modernas de vários Estados (Suíça, Dinamarca, Irlanda, França, Áustria, Alemanha, Itália, Suécia)."( CANOTILHO, José Joaquim Gomes. Direito Constitucional e Teoria da Constituição, $7^{\circ}$ ed., Coimbra: Almedina, 2003, p. 294-295.)

${ }^{28}$ Ovídio refere que "Fica porém evidente que o pressuposto básico para o estabelecimento de uma democracia consistente e durável deve ser buscado não apenas na formação juridicamente perfeita do dispositivo estatal mas, fundamentalmente, no estabelecimento de condições sócio-culturais que possibilitem o surgimento de verdadeiros e autênticos cidadãos." (SILVA, Ovído A. Baptista da. Participação e processo coord. Ada Pellegrini Grinover, São Paulo: RT, 1988, p. 108).

- PARTICIPAÇÃO - pela própria manifestação(voto/referendo) de cada indivíduo ou através de suas associações. 
do dito Estado Democrático de Direito que é buscado e deveria ser veridicamente implantado.

O Poder Judiciário possui problemáticas internas naturais assim como os outros Poderes, mas, é totalmente diferente dos demais em relação à participação popular, pois aqui o cidadão que reclama do Judiciário uma solução receberá uma resposta a seu clamor - seja através de decisões interlocutórias ${ }^{29}$ ou ainda através de sentenças ${ }^{30}$ - e poderá contribuir, agindo nos autos do processo através de seu patrono, para a solvência da problemática que se impunha sobre determinada questão ${ }^{31}$.

É disso que se está a falar, de participação efetiva e real, e não de uma mera participação esporádica que se dá somente de quatro em quatro anos por conseqüência das eleições que são efetivadas em cada um de seus níveis.

Assim, se deve pensar, hodiernamente, em um processo civil que propicie a participação dos cidadãos ${ }^{32}$, seja via ação individual ou ainda por ações coletivas, onde a participatividade será ainda maior, pois envolverá diversas pessoas que se manifestarão e serão ouvidas pelo Judiciário, seja via petições, recursos e manifestações através de seus procurados, ou ainda, como testemunhas ou infor-

\footnotetext{
${ }^{29}$ Sobre decisões interlocutórias vide MARINONI, Luiz Guilherme [et. all.]. Código de direito processual civil comentado, São Paulo: RT, 2008, p. 195 e ss. Também se localize as ponderações pontuadas de NERY JUNIOR, Nelson [et. all.]. Código de processo civil comentado e legislação extravagante, $10^{\circ}$ ed. rev., ampli. e atual., São Paulo: RT, 2007, p. 431.

${ }^{30}$ Sobre a noção de sentença ver MARINONI, Luiz Guilherme [et. all.]. Código de direito processual civil comentado, São Paulo: RT, 2008, p. 420 e ss. Ainda observe-se NERY JÚNIOR, Nelson [et. all.]. Código de processo civil comentado e legislação extravagante, $10^{\circ}$ ed. rev., ampli. e atual., São Paulo: RT, 2007, p. 665. ${ }^{31}$ No sentido de observar o bem julgar propiciador da construção da democracia vide GARAPON, Antonie. Bem julgar: ensaio sobre o ritual judiciário, Lisboa: Instituto Piaget, 1997, p.327.

${ }^{32}$ Neste sentido, deve-se observar obra interessantíssima do eminente jurista Sálvio de Figueiredo Teixeira, onde o autor preleciona um aprimoramento do processo civil como garantia da cidadania, sendo essa noção uma realidade importantíssima, sendo, claramente, esse o motivo de busca de aperfeiçoamento do direito processual civil, não reduzindo sua relevância a uma mera técnica, mas sim o elevando ao patamar de garantidor de direitos e de modo de participação efetiva. Vide: TEIXEIRA, Sálvio de Figueiredo. As garantias do cidadão na justiça, coord. Sálvio de Figueiredo Teixeira, São Paulo: Saraiva, 1993, p.79 e ss.
} 


\section{8}

mantes. Aqui se pode observar participação, algo que é intrínseco da democracia, embora saibamos que ela pode ser participativa ou representativa ${ }^{33}$.

Essa é a nova realidade que se apresenta em relação a democracia, onde o judiciário ${ }^{34}$, através do processo, realizará a participação efetiva da população frente as problemáticas individuais e sociais que venham a se por.

A antiga idéia de que democracia só poderia ser obtida através do Poder Legislativo, por outros através do Executivo, o que reduziria o exercício da democracia a uma mera participação eventual onde os cidadãos escolheriam seus representantes e, após tudo isso, nada fariam, aguardando que os representantes efetivassem todos os anseios da comunidade local, municipal, estadual e até nacional.

Esse modelo deve ser observado com outros olhos, o olhar da inefetividade que reduziu a democracia a uma mera previsão formal da Carta Política de 1988, mas que foi constituída para ser não só formalmente existente mais também materialmente, aplicando no mundo real essa noção democrática que seria, sem duvida, o ideal para, se não salvar a nação, pelo menos melhorar a situação atual de nosso país.

Para escaparmos dessa realidade necessitamos pensar em democracia ligada a um Poder que tenha uma maior possibilidade de promoção da participação efetiva e real dos cidadãos, respondendo a esses todos os reclames que forem efetivados. Pelo que se percebe

\footnotetext{
33 Para observar com mais vagar a noção de democracia representativa ver: AMARAL, Roberto. A democracia representativa está morta; viva a democracia participativa. In/; Direito Constitucional. Estudos em homenagem a Paulo Bonavides, São Paulo: Malheiros, 2003, p. 19.

${ }^{34}$ Sobre a noção de que o Poder Judiciário é o novo "fiador" da democracia vide: Ovídio A. Baptista da Silva in: SILVA, Ovídio A. Baptista da. Democracia e sociedade de massa - www.Baptistadasilva.com.br/artigos. verbis: "Esta é a questão que nos obriga a pensar numa profunda descentralização do poder, capaz de aproximar-nos do povo, permitindo o exercício autêntico de um regime democrático, de que o Poder Judiciário terá de ser o fiador. A jurisdição, num regime verdadeiramente democrático, ao contrário do nosso, deve ser o agente "pulverizador" do Poder, o órgão produtor de micro-poderes, que possam contrabalançar o sentido centralizador que os outros dois ramos zelosamente preservam, para conservarem-se distantes do povo."
} 
não há outro Poder que possa propiciar isso, com seriedade e qualidade, do que o Poder Judiciário.

Esse Poder tem problemas, assim como todos os outros, mas dentro de suas condições propicia claramente muito mais acesso e participação do cidadão do que qualquer outro Poder ${ }^{35}$.

Por isso, apregoa-se com esse trabalho a busca de aplicação efetiva de democracia ao Poder Judiciário, fazendo isso através do processo, que é, para dualistas, meio de resolução dos litígios que pode gerar a democracia que se busca a tanto tempo ${ }^{36}$.

Com toda essa possibilidade de participação popular através do processo poderá ser possível, realmente, escutar aquilo que os membros de nossa sociedade têm a dizer, abstraindo as suas dificuldades e celeumas, visando sempre a solução eficaz que, sendo colocada em prática, pode gerar, em decorrência do alto nível de participatividade, maior justiça ${ }^{37}$.

${ }^{35}$ Essa participação se dá através da plenitude de defesa que o processo civil propicia as partes, onde os cidadãos que participam da lide poderão utilizar de todas as formas legalmente previstas para comprovarem o seu direito ou ainda se defender de uma determinada demanda. Nesse sentido averiguar belíssima construção esposada pelo Jurista Ovídio A. Baptista da Silva in: SILVA, Ovídio A. Baptista da. As garantias do cidadão na justiça, coord. Sálvio de Figueiredo Teixeira, São Paulo: Saraiva, 1993, p.149 e ss.

${ }^{36}$ Para aqueles que têm uma compreensão dualista do processo vejam SANTOS, Moacyr Amaral. Primeiras linhas de direito processual civil: adaptadas ao novo código de processo civil, São Paulo: Saraiva, 1980, p. 11. "Processo é uma operação por meio da qual se obtém a composição da lide. Conquanto exara, a noção assim formulada não exprime com a necessária clareza um conceito compreensivo de todos os elementos característicos da coisa definida." Vide também MARINONI, Luiz Guilherme [et. all.]. Código de direito processual civil comentado, São Paulo: RT, 2008, p. 279 e ss; NERY JÚNIOR, Nelson [et. all.]. Código de processo civil comentado e legislação extravagante, $10^{\circ}$ ed. rev., ampli. e atual., São Paulo: RT, 2007, p. 165.

${ }^{37}$ Sabemos que o critério de justiça é algo relativo, sendo por vezes inatingível, o que dificulta muito essa busca por aquilo que se entende ser justo, pois o justo pode ser visto conforme o seu ângulo, já que ara uma parte o justo será a procedência de seus pedidos, através da ação judicial, e para a parte adversa o justo será a improcedência dos pedidos. Eis a questão que é complexa por sua natureza. No dizer de Nelson Nery Júnior é uma utopia, in : NERY JÚNIOR, Nelson [et. all.]. Código de processo civil comentado e legislação extravagante, $10^{\circ}$ ed. rev., ampli. e atual., São Paulo: RT, 2007, p. 687. Ainda podemos perceber que justiça é algo que se busca mas que é complexo de ser atingido, até pelo fato de que existem partes e versões distintas das questões vivenciadas, assim o que se poria esperar

RPGE, Porto Alegre, v. 33, n. 70, p. 87-124, 2012 
Assim, essa nova realidade de analise deve ser bem observada pelos juristas e demais interessados, para que possamos agir indo ao encontro da democracia e não simplesmente pretendê-la sem, realmente, realizá-la.

\section{O PROCESSO CIVIL PARTICIPATIVO}

O processo civil por sua natureza é participativo ${ }^{38}$, pois envolve diferentes noções e realidades sobre uma mesma coisa ou bem. Neste ponto nasce a lide ${ }^{39}$, que nada mais é do que uma pretensão resistida, onde nasce o "conflito" ou litígio.

Em verdade a parte autora busca a proteção de uma determinada situação que juridicamente lhe é possível em desfavor de outro sujeito, que é o réu, que vem a resistir à pretensão que detém o demandante, sendo esse conflito de posições jurídicas levadas ao

seriapelo menos uma decisão de qualidade para que possamos nos aproximar dessa noção de justiça assim como dia Chaim Perelman, Ética e direito, São Paulo: Martins Fontes, 1996, p. 377). Por fim vejamos o que relata Andrea Proto Pisani refere que "os institutos de direito material estão destinados, diria que naturalmente, a mudar de acordo com o surgimento $e$ a diferente avaliação dos interesses em conflito em relação à fruição dos bens materiais e imateriais. Diferentemente dos institutos de direito material, os institutos processuais que visam garantir a tutela jurisdicional dos direitos nascem, por assim dizer, não apenas com o selo terreno, mas com aquele da eternidade, que lhes é aposto por seu próprio destino de garantir a realização da justiça"(Andrea Proto Pisani, Revista da Escola da Magistratura do Rio de Janeiro, n. 16, 2001, p. 23).

38 Já dizia Calmon de Passos que o processo era um instrumento político de participação, assim verbis: Acredito estejamos caminhando para o processo côo instrumento político de participação. A democratização do Estado alcançou o processo à condição de garantia constitucional; a democratização da sociedade fá-lo-á instrumento de atuação política. Não se cuida de retirar do processo sua feição de garantia constitucional, sim fazê-lo ultrapassar os limites da tutela dos direitos individuais, como hoje conceituado. (PASSOS, José Joaquim Calmon de. Participação e processo coord. Ada Pellegrini Grinover, São Paulo: RT, 1988, p. 95.) ${ }^{39}$ Assim vale utilizar a conceituação esposada pelo nobre jurista Moarcyr Amaral Santos: "Lide, portanto, é o conflito de interesses qualificado pela pretensão de um dos interessados e pela resistência do outro. Ou, mais sinteticamente, lide é o conflito de interesses qualificado por uma pretensão resistida" (SANTOS, Moacyr Amaral. Primeiras linhas de direito processual civil: adaptadas ao novo código de processo civil, São Paulo: Saraiva, 1980, p. 09.) 
Judiciário, que na pessoa do juiz, que é membro de juízo, definirá em primeiro grau o que seja coerente em termos de direito ${ }^{40}$.

No meio de tudo isso ocorrerá diversas manifestações, a começar pela petição inicial ${ }^{41}$ da parte autora da demandante, que poderá ser respondida conforme as formas de respostas que são elencadas pela norma processual civil vigente. Também haverá possibilidade recursal para ambas as partes o que mais uma vez demonstra o alto grau de participatividade que é dotado o processo ${ }^{42}$.

Além de toda essa realidade o processo civil brasileiro ainda é colaborativo ${ }^{43}$, onde as partes não somente devem se relacionar no processo, como também dialogar e colaborar para que a solução mais equânime seja adotada. Nessa colaboração processual devem participar todos os agentes que fazem parte ou que se envolvem com a demanda, desde autor, réu, juiz e até os membros do juízo - como o próprio escrivão e demais cartorários -.

Quando se fala em colaboração no processo muitos podem pensar em utopia, mas o que nos parece é que essa noção de colaboração no processo civil é real e deve ser observada com olhos

\footnotetext{
${ }^{40}$ Muito se discute sobre a autonomia do direito, assim nas palavras do douto jurista português A. Castanheira Neves é, em verdade, uma capacidade de existência do direito independentemente de qualquer outra coisa ou ciência, como se fosse o direito auto-subsistente. ( NEVES, Antônio Castanheira. O direito hoje em com que sentido? Lisboa: Editora Piaget, 2002, p. 21).

${ }^{41}$ A petição inicial é o pedido inicial que é efetivado através de uma peça vestibular que obedecerá os requisitos do art. 282 e 283 do Código de Processo Civil. Neste sentido NERY JÚNIOR, Nelson [et. all.]. Código de processo civil comentado e legislação extravagante, $10^{\circ}$ ed. rev., ampli. e atual., São Paulo: RT, 2007, p. 549 e ss.

${ }^{42}$ Nesse sentido vem Calmon de Passo in: PASSOS, José Joaquim Calmon de. Participação e processo coord. Ada Pellegrini Grinover, São Paulo: RT, 1988, p. 84. "Nesses termos não constitui despropósito associar-se processo a democracia, porquanto, com esse relacionamento, pretende-se, justamente, denunciar a necessária dimensão política do processo jurisdicional e tornar manifesto os vínculos que prendem ao processo econômico."

${ }^{43}$ Nesse sentido devemos observar a recente obra que trata da questão da colaboração no processo civil, que foi encabeçada pelo processualista Daniel Mitidiero, sendo uma nova perspectiva que observa do dever de cooperação - que foi tempos atrás estudado em Portugal - de todos os sujeitos envolvidos no litígio. (MITIDIERO, Daniel. Colaboração no processo civil: pressupostos sociais, lógicos e éticos, São Paulo: RT, 2009, p. 63 e ss.
}

RPGE, Porto Alegre, v. 33, n. 70, p. 87-124, 2012 


\section{2}

positivos, pois pode trazer não só uma melhor solução da lide, mas, também, uma rápida resolução das problemáticas que foram postas às mãos do Judiciário ${ }^{44}$.

É frente a tudo isso que o processo se coloca como meio de realização da democracia, por proporcionar, claramente, a participação e livre manifestação das partes, desde que respeitem os limites impostos pelo próprio codex processual.

Mais uma vez se faz a ligação entre a idéia de democracia e o Processo Civil e conseqüentemente ao Poder Judiciário, que através de suas decisões, que serão motivadas, poderá efetivar justiça ${ }^{45}$ e realizar a função social de vários institutos de direito material que foram construídos visando a melhor condição de vida dos cidadãos.

Natural é pensar em democracia através de um meio como o Processo, onde haverá oitiva das partes - através de depoimento pessoal $^{46}$ - das testemunhas - na oitiva das testemunhas ${ }^{47}-e$ até oitiva dos próprios patronos - que se dará através dos debates orais ${ }^{48}$ ou até da sustentação oral no Tribunal -.

Realizar a democracia efetiva, e não "democracia do papel", não é algo fácil de ser alcançado, mas extremamente possível, visto que com todas as qualidades que o processo oferta pode ser garantida a participação e representação popular.

\footnotetext{
${ }^{44}$ Levemos como exemplo a idéia da Justiça Restaurativa, que hodiernamente é estudada e é interessante pois parte da idéia de composição da lide, de solução da lide sem o transcurso natural da lide, que é, por sinal, muito delongado. Sobre justiça restaurativa deve ser miradas as lições que o eminente jurista SANTOS, Boaventura de Souza. Para uma revolução democrática da justiça, $2^{\circ}$ ed., São Paulo: Cortez, 2008, p. 58.

${ }^{45}$ Deve-se buscar a justiça, que é sim o fundamento e a esperança de todos que demanda, não buscando, entretanto, a justiça estática, que não será capaz de chegar ao ponto que a justiça efetiva poderia chegar. Assim vejamos Agnes Heller quando fala da "justiça estática" - justiça do tirando, justiça da verdade do senhor. (Agnes Heller, Más Allá de la justicia, Barcelona: editora crítica, 1990, p. 311 e ss.) 46 Sobre o depoimento pessoal observar MARINONI, Luiz Guilherme [et. all.]. Código de direito processual civil comentado, São Paulo: RT, 2008, p. 347 e ss.

47 Idem., p. 388; NERY JÚNIOR, Nelson [et. all.]. Código de processo civil comentado e legislação extravagante, $10^{\circ}$ ed. rev., ampli. e atual., São Paulo: RT, 2007, p. 639 e ss.

${ }^{48}$ Nesse sentido vale apena observar as ponderações de MARINONI, Luiz Guilherme [et. all.]. Código de direito processual civil comentado, São Paulo: RT, 2008, p. 419.
} 
Muitas outras questões problemáticas ligadas à temática surgiram, e algumas delas afetaram inclusive o Judiciário, que acaba sendo obrigado a agir além de sua competência para que se garanta, pelo menos, o mínimo de justiça.

Estamos a falar, desta feita, de algo que se intitulou de ativismo judicial ${ }^{49}$, onde o Poder Judiciário ${ }^{50}$ é obrigado a agir, legislando de forma indireta, em decorrência da verdadeira inação do Legislativo, que é o responsável pela elaboração de normas que venham a positivar condutas e preservar direitos, que não praticou os atos legislativos necessários para respaldarem direitos que simplesmente estariam protegidos caso o esse Poder cumprisse a sua função social.

Assim, o Judiciário mais uma vez acaba por agir, resolvendo no caso onde haja dúvida, em decorrência na inação do Legislativo, a problemática, sendo isso decorrente da idéia de que nenhuma lesão ou ameaça ao direito será procedida sem a devida analise e apreciação por parte do Poder Judiciário ${ }^{51}$, decisões que serão

\footnotetext{
${ }^{49}$ Essa ocorrência da qual o Legislativo é o responsável por não legislar sobre as matérias quando o deveria ter feito, faz com que tudo isso venha a desemborcar no Judiciário fazendo nascer o ativismo judicial, que para muitos é ausente de embasamento, mas que para outros é plenamente possível. Tudo isso nos faz chegara a idéia de judicialização da política, nesse condão SANTOS, Boaventura de Souza. Para uma revolução democrática da justiça, $2^{\circ}$ ed., São Paulo: Cortez, 2008, p. 23; Também observas as colocações de ROCHA, Alvaro Felipe Oxley da. Sociologia do direito: A magistratura no espelho, São Leopoldo: Editora UNISINOS, 2002, p. 23 e ss.

${ }^{50}$ ROCCO, antigo professor da Universidade de Napoli, ao tratar da função jurisdicional in ROCCO, Ugo. Trattato di diritto processuale civile V. I, $2^{\circ}$ ed., Torino: Topografia Sociale Torinese, 1966, p.46-48; Também mirar as ponderações de LOPES, José Reinaldo de Lima, in: FARIA, José Eduardo(coord.) [et. all]. Direito e justiça: A função social do judiciário, São Paulo: Ática, 1989, p. 123 e ss.

${ }^{51}$ Realizando-se a chamada efetividade do processo, que está prevista no art. $5^{\circ}$, XXXV da Constituição Federal, assim como refere Cassio Scarpinella Bueno in: BUENO, Cassio Scarpinella. Curso sistematizado de direito processual civil: teoria geral do direito processual civil: vol. 1, São Paulo: Saraiva, 2007, p. 146-147.
}

RPGE, Porto Alegre, v. 33, n. 70, p. 87-124, 2012 


\section{4}

fundamentadas ${ }^{52}$, gerando com isso uma segurança e desde logo a participação do cidadão envolvido na questão.

Frente a tudo isso se torna complexo falar de democracia em relação a um Poder que se quer cumpre o seu papel que é legislar, quanto mais realizar a democracia que garantiria a participação popular que é tão aguardada por todos.

Destarte, não se está aqui a santificar o Judiciário, mas, sim, buscar ao máximo proporcionar a ocorrência da democracia que é uma busca constante de grande parte dos juristas, sabendo que muitas coisas poderiam mudar para melhor.

É nesse meio, o do processo, é que encontramos um alto grau de participatividade, onde as partes podem participar de forma ativa ou até mesmo passiva, contribuindo para a elaboração do desfecho judicial da questão, que gerará, sem dúvida, conseqüências práticas relevantes no mundo dos fatos, onde o reflexo da democracia realmente influi muito, garantindo direitos que cada cidadão detenha $e$

\footnotetext{
${ }^{52} \mathrm{O}$ princípio da fundamentação é extremamente relevante e necessário para a composição adequada do processo, nesse sentido vide como bem assevera o art. 93, IX da Carta Política, verbis: "IX todos os julgamentos dos órgãos do Poder Judiciário serão públicos, e fundamentadas todas as decisões, sob pena de nulidade, podendo a lei limitar a presença, em determinados atos, às próprias partes $e$ a seus advogados, ou somente a estes, em casos nos quais a preservação do direito à intimidade do interessado no sigilo não prejudique o interesse público à informação". Ademais, a fundamentação que é requisito juridicamente necessário para que uma decisão seja apta a gerar seus efeitos naturais, deve contar com uma fundamentação eficaz ao ponto de convencer aos sujeitos que recebe a motivação emanada pelo Judiciário, fugindo-se da falsas fundamentações que são altamente reprovadas, assim como já referia o douto jurista Ovídio A. Baptista da Silva, verbis: "As falsas fundamentações que, hoje, são empregadas pelo Poder judiciário, são responsáveis por arbitrariedades que muito prejudicam o desenvolvimento nacional". ( SILVA, Ovídio A. Baptista da. Jurisdição, direito material e processo, Rio de Janeiro: Forense, 2008, p. 141). Essas sentenças que estão com "roupagem formosa", em relação à esperada fundamentação, não passam de mero pronunciamento judicial sem a devida análise por parte do julgador, o que gera em diversas hipóteses "sentenças arbitrarias". (neste sentido Genaro R. Carrió e Alejandro D Carrió, El recurso extraordinario por sentencia arbitrria, Buenos Aires, Abeledo-perrot, 1983).
} 
que faça valer através do processo e do Poder Judiciário, fazendo-se praticada a dignidade humana ${ }^{53}$.

Frente a toda essa realidade, não há como pensar em democracia efetiva distante do processo e do Judiciário, por ser perceptível a notada possibilidade de participação popular que é proporcionada pelo processo e por todos os seus recursos e meios existentes, se não obtendo a democracia, pelo menos se aproximando dela.

\section{PARA UMA REVOLUÇÃO DEMOCRÁTICA DA JUSTIÇA}

Frente ao sistema que adotamos em nosso país que, em tese, prioriza pela obtenção da justiça, que sabemos ser algo difícil, torna-se necessário começar a pensar em uma forma de alcança a tão esperada democracia, alterando a realidade de nossa sociedade.

Em nosso país erroneamente vigora, atualmente, a noção de que Lei é direito ${ }^{54}$ - o que se tornou um dogma ${ }^{55}$-, algo que ve-

${ }^{53}$ Ingo Wolgang Sarlet, conceitua dignidade da pessoa humana como sendo uma
"qualidade intrínseca e distintiva de cada ser humano que o faz merecedor do
mesmo respeito e consideração por parte do Estado e da comunidade, implicando,
neste sentido, um complexo de direitos e deveres fundamentais que assegurem a
pessoa tanto contra todo e qualquer ato de cunho degradante e desumano, como
venham a lhe garantir as condições existentes mínimas para uma vida saudável,
além de propiciar e promover sua participação ativa e co-responsável nos destinos
da própria existência e da vida em comunhão com os demais seres humanos "(
SARLET, Ingo Wolfgang. Dignidade da Pessoa Humana e Direitos Fundamentais
na Constituição Federal de 1988, Porto Alegre: Livraria do advogado, 2001, p. 60).
Ainda, No dizer de Luis Prieto Sanchis a dignidade da pessoa humana "dista de
ser una respetable reliquia de la arqueologia cultural"(9), compreende um modo
de entender-se os direitos fundamentais. (SANCHIS, Luis Prieto - Estúdios sobre
Derechos Fundamentales, p. 26 ). Devemos ter a liberdade de consultar o douto
jurista português Canotilho in: CANOTILHO, José Joaquim Gomes. Estudo sobre
direitos fundamentais, $1^{\circ}$ ed., São Paulo: RT, 2008, p. 247. Por fim, vide: ALEXY,
Robert. Teoria dos direitos fundamentais, tradução de Virgilio Afonso da Silva,
São Paulo: Malheiros, 2008, p.111.
54 Kelsen, quando em sua obra Teoria pura do direito constrói a idéia de que lei
é direito e que por essa razão deveríamos estar submissos a lei, vide: KELSEN,
Hans. Teoria pura do direito, 4 ' Ed., São Paulo: Martins Fontes, 1994, p. 33 e ss.
55 Muito interessante observar a argüição feita pelo filósofo alemão Arthur
Shopenhauer, que critica o apego ao dogma, in: SCHOPENHAUER, Arthur. Como
vencer um debate sem precisar ter razão: em 38 estratagemas, trad. Daniela Caldas

RPGE, Porto Alegre, v. 33, n. 70, p. 87-124, 2012 


\section{6}

ridicamente não o é, por ser clara e óbvia a idéia de que o direito é construído a partir de uma junção da principiologia e das regras positivadas, alindo esses dois aos costumes e demais formas de proteção do "direito".

Essa revolução que é aduzida está embasada nas lições do renomado jurista português Boaventura de Souza Santos, que defende essa idéia em sua obra ${ }^{56}$.

Claramente muita coisa precisa mudar, desde as universidades, as escolas da magistratura, os professores, os alunos e até mesmo os autores ou eruditos do direito.

Em relação às Universidades muitas críticas são efetivadas, em um país como o nosso que começa a propiciar o acesso aos bancos acadêmicos com maior força a pouco tempo, em decorrência do elevado numero de Universidades que o nosso país possui, falando-se exclusivamente nessa análise das faculdades de direito, ver-se um verdadeiro festival de Universidades ${ }^{57}$.

Não se deve ser contra as instituições de ensino, muito antes pelo contrario, mas se deve, sim, com toda a força, preservar as ins-

e Olavo de Carvalho, Rio de Janeiro: Topbooks, 1997, p. 168-169. Para o saudoso jurista Ovídio A. Baptista da Silva "a transformação paradigmática, da qual não nos é possível escapar, sob pena de renunciar ao direito, como instrumento superior de resolução de conflitos sociais, ao mesmo tempo em que permitirá resgatar a figura do juiz "responsável" - oposto ao juiz do sistema, que não comete injustiças, porquanto sua missão está limitada a declarar a injustiça da lei -, determinará que o pensamento jurídico renuncie ao dogmatismo, para recuperar a função hermenêutica na compreensão de textos, sob o pressuposto epistemológico de que o texto carrega várias soluções jurídicas possível, para, enfim, mostrando que texto e norma não são a mesma coisa, reentronizar a retórica como ciência da argumentação forense, que o pensamento linear dos juristas geômetras do século XVII pretendeu eliminar do direito processual". (SILVA, Ovídio A. Baptista da. Jurisdição, direito material e processo, Rio de Janeiro: Forense, 2008, p. 148.) Também observe-se Castanheira Neves (O instituto dos "assentos" e a função jurídica dos tribunais supremos, Coimbra, 1983, p. 584).

${ }^{56}$ Utilizaremos nesse capítulo SANTOS, Boaventura de Souza. Para uma revolução democrática da justiça, $2^{\circ}$ ed., São Paulo: Cortez, 2008; por ser uma obra muito realista e inteligente, explorando pontos e formas de raciocínio que nos levaram a entender a proposição do autor.

${ }^{57}$ Boaventura critica o elevado número de Universidades existentes em nosso país, o que pode deixar o ensino jurídico em verdadeira calamidade e cada vez mais deficitário, in: SANTOS, Boaventura de Souza. Para uma revolução democrática da justiça, $2^{\circ}$ ed., São Paulo: Cortez, 2008, p. 72. 
tituições com qualidade de ensino e de formação ético-profissional. Sabe-se que hodiernamente isso tem sido incomum em grande parte das Universidades.

Deve-se tomar o cuidado devido para que os acadêmicos tenham qualidade, sob pena de transformar a sociedade que dotará profissionais incapazes de alcançarem as expectativas.

Assim, a crítica fica para o excessivo número de instituições efetivamente descomprometidas com o ensinar, mas sim preocupadas com o lucrar. Deve-se preservara as boas universidades $e$ a qualidade do ensino para que nossa sociedade possa "herdar" bons profissionais capazes de solver as problemáticas jurídicas que a cada dia se tornam mais complicadas em decorrência da natural complexidade da sociedade.

Outras instituições que devem ser criteriosas e efetivas são as escolas da Magistratura ${ }^{58}$, onde os acadêmicos são preparados para o ingresso na carreira jurídica via concurso público, ocupando os cargos jurídicos que fazem parte da atuação natural.

Essas escolas são responsáveis pela formação tanto dos acadêmicos como dos próprios magistrados que são os participantes da relação jurídico-processual, sendo o sujeito que, agindo no intuito de fazer justiça, decidem os processos e as questóes que são levadas diariamente ao Judiciário.

Daí a tamanha importância de investir na formação dos magistrados ${ }^{59}$, que poderão, com uma boa formação, fazer a diferença em um Poder Judiciário - saberá interpretar ${ }^{60}$ adequadamente as questões - que deve estar atento e preocupado em atender com qualidade os cidadãos que vão ao Judiciário buscar aquilo que pretendem, qual seja a solvência do conflito.

\footnotetext{
${ }^{58}$ Idem., p. 76 e ss. Neste peculiar Boaventura refere que as escolas da magistratura devem propiciar a formação adequada aos magistrados, para que eles possam desenvolver a aptidão de pensar para solucionar as causas judiciais que se colocarem a sua frente, cumprindo com as expectativas que são depositadas pela sociedade no Judiciário.

${ }^{59}$ Idem., p. 66 e ss. Sendo requisito básico a devida preparação dos novos membros do Poder Judiciário, que devem ser treinados para o exercício qualificado e profissional da sua função pública.

${ }^{60}$ Sobre a hermenêutica filosófica, que se vale a noção de interpretação, deve ser consultado GADAMER, Hans-Georg. Verdade e método II, trad. Enio Paulo Gianchini e Maria Sá Cavalcante Schuback, Petrópolis: Vozes, 2002, p. 111 e ss.
} 


\section{8}

Ademais, deve haver uma preocupação com os professores, que são os efetivos responsáveis pela formação de muitos juristas que, naturalmente, passam pelos bancos acadêmicos, seja na graduação como nos cursos de pós-graduação.

Os professores devem estar comprometidos em ensinar e não em apenas lucrar ${ }^{61}$ com o ensino, devem estar comprometidos com a causa do ensino jurídico de qualidade, sendo para o aluno um estimulo e inspiração de conhecimento e ética.

Por lógica, é de suma importância às Universidades terem professores capacitados e qualificados para que uma realidade caótica mude e para que possamos nos aproximar da idéia de democracia. A junção de todos esses fatores pode aproximar da nossa realidade a democracia efetiva, vencendo a democracia de papel que até o presente momento é um sonho.

Além de pensar na preparação dos professores, o que é naturalmente necessário e importante, deve-se pensar também nos acadêmicos, onde se deve buscar manter nesses um comprometimento e dedicação essenciais. Essas qualidades devem fazer parte das características dos acadêmicos para que o ensino mantenha a qualidade e esses possam se tornar profissionais de qualidade servindo à sociedade.

Os acadêmicos por vezes não são tão preocupados com sua formação acadêmica ${ }^{62}$, achando que isso não influenciará na condição profissional, quando, naturalmente, influenciará e muito. Um acadêmico forte que busca e se dedica aos estudos ingressará no mercado profissional com muito mais facilidade do que os demais

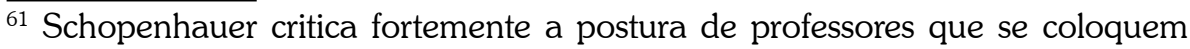
no mercado das universidades com o grande intuito de lucrar, por ser essa uma postura contrária ao do ensino de qualidade. Assim, para o autor devem ser afastados das academias esses tipos de professores que mais prejudicam do que efetivamente ensinam. Vide: SCHOPENHAUER, Arthur. A arte de escrever, trad. Pedro Sussekind, Porto Alegre: L\&PM, 2008, p. 19.

${ }^{62}$ Idem., p. 20. Os alunos buscam informações de todas as índoles sem se preocuparem realmente com o que é relevante e com sua formação acadêmica, o que trará enormes prejuízos e conseqüências que tornaram os acadêmicos despreparados e enfraquecidos, não podendo auxiliar nas efetivas dificuldades da sociedade.
} 
que não dedicam tempo ao estudo. Nossa sociedade sofre muito com isso, o que também prejudica a concretização da democracia que se busca implantar em nosso país.

Por fim, observemos os intelectuais doutrinadores, que são muito mais preocupados em escrever obras e serem eruditos, o que não deve ser recriminado mais sim estimulado desde que esse erudito saiba utilizar as qualidades que possui $e$ as pesquisas que efetivou ${ }^{63}$.

Os eruditos por vezes escrevem obras que não tem um propósito efetivo, que não tem uma riqueza intelectual, sendo por mera imitação do que os anteriores escreveram ${ }^{64}$. Essa ausência de comprometimento macula toda a comunidade jurídica que acaba lendo as obras desses autores que deveriam estar preocupados em repassar conhecimento, e não como alguns poucos que se preocupam com a lucratividade de suas escritas e habilidade. Deve-se enfatizar que os eruditos do direito são necessários, mas devem buscar cumprir o seu papel, a sua função social, qual seja a de ensinar e de através de sua fala e escrita repassar conhecimento e cultura.

Com o cuidado de todos esses fatores poderemos nos aproximar da noção de democracia, que envolverá a efetiva participação. Para tanto, como refere Boaventura de Souza Santos devemos fazer uma "revolução" em busca da democracia, buscando corrigir os erros que sabemos existir e a partir disso agir em busca da democracia que poderá ser alcançada através do processo.

\section{A DEMOCRACIA REALIZADA ATRAVÉS DAS GARAN- TIAS CONSTITUCIONAIS DO PROCESSO}

Frente a toda essa realidade que analisamos até então, faz-se necessário compreender que a democracia poderá ser passível de

\footnotetext{
${ }^{63}$ Idem., p. 21. Essa critica é efetivada por Schopenhauer, de forma brilhante, quando relata a situação de vários eruditos que não se preocupam com a realidade das questões, mas sim, em escrever seus livros, tornarem-se conhecidos e lucrarem com isso, essa prática deve ser repudiada, devemos buscar a formação de eruditos comprometidos com o conhecimento, que escrevam suas obras pensando na solução dos problemas e de tornar a nossa sociedade uma democracia real, ou ao menos tentar fazer isso.

${ }^{64}$ Idem., p. 22.
}

RPGE, Porto Alegre, v. 33, n. 70, p. 87-124, 2012 


\section{0}

realização através do processo e do Poder Judiciário, graças às garantias constitucionais do processo ${ }^{65}$.

O processo civil brasileiro que é um dos meios de obtenção de democracia é dotado de grandiosa formação principiológico, estando esses princípios disposto tanto na Carta Magna de 1988 como também no Código de Processo civil, regulando de forma pontuada processo.

Dentre os diversos princípios encontrados na Constituição Federal, trataremos de alguns dentre os quais o do devido processo legal, contraditório, ampla defesa, efetividade da prestação da tutela jurisdicional, celeridade e razoável duração do processo.

O devido processo legal ${ }^{66}$ é um princípio muito importante, se não o mais, por ser o princípio gênero do qual os demais derivam $e$ são espécies. Esse princípio que tem origem no direito americano é a base forte do ordenamento jurídico ${ }^{67}$ Processual Civil brasileiro $e$ por essa sua importância sempre foi bem tratado pela doutrina que o interpreta de forma coerente, visando sempre tornar o processo uma manifestação democrática.

Quando se trata de observar o devido processo legal ${ }^{68}$ se está a falar de um processo que obtenha um curso natural, que seja or-

${ }_{65}$ A Constituição Federal de 1988 traz em seu arcabouço diversos princípios processuais que são de imensa valia para o direito processual civil brasileiro, dos quais devem ser consultados nas obras: PORTANOVA, Rui. Princípios do processo civil, $6^{\circ}$ ed., Porto Alegre: Livraria do Advogado, 2005; e NERY JÚNIOR, Nelson. Princípios do processo civil na constituição federal, $7^{\circ}$ ed. rev. atual., São Paulo: RT, 2002.

${ }^{66}$ Sobre esse princípio aduz Nelson Nery Júnior que " O princípio fundamental do processo civil, que entendemos como base a qual todos os outros se sustentam, é o do devido processo legal, expressão oriunda da inglesa due process of Law. (...)" in NERY JÚNIOR, Nelson. Princípios do processo civil na constituição federal, $7^{\circ}$ ed. rev. atual., São Paulo: RT, 2002, p. 32.

${ }^{67} \mathrm{BOBIO}$, Norberto. Teoria do ordenamento jurídico, trad. Maria Celeste Cordeiro Leite dos Santos, $10^{\circ}$ ed., Brasília: Editora Universidade de Brasília, 1999, p. 71 e ss.

68 Também sobre o devido processo legal vale consultar a bela obra de Cassio Scarpinella Bueno in: BUENO, Cassio Scarpinella. Curso sistematizado de direito processual civil: teoria geral do direito processual civil: vol. 1, São Paulo: Saraiva, 2007, p. 104 e ss. Rememore-se que para alguns quando se trata deste princípio, ora observado, dever-se-ia chama de devido processo constitucional e não como é chamado de devido processo legal. Idem., p. 106. 
ganizado e se preste a seu fim, que é, dentro do possível, a solvência do conflito $e$ a obtenção de justiça.

Em verdade o processo será adimplente a este princípio quando respeitar uma lógica de atos concatenados que venham a buscar a produção de provas que possibilitarão, dentro de um prazo razoável, a solução da lide que se colocou às portas do Judiciário. O devido processo legal está relacionado com uma idéia de processo organizado, que respeite certo formalismo ${ }^{69}$, mas desde que seja realmente valorativo $^{70}$ e não um formalismo que desprestigie o seguimento célere da demanda e muito menos de um formalismo que se apegue ao extremo a forma sem prezar pela obtenção da solução efetiva da problemática. Essa é a noção de devido processo legal implantada em nosso país assim como em outros tantos, um processo que siga o seu devido curso, que pela garantia de participação processual gerará, em grande parte de seus conflitos processuais a possibilidade de amplitude de defesa e o alcance de justiça.

O contraditório ${ }^{71}$ que também é um princípio processual-constitucional é muito relevante por ser a forma pela qual se possibilita a parte demandada tomar conhecimento do pleito que se põe em seu desfavor. Esse contraditório se dá através das notificações processuais, das quais o maior exemplo é a citação da parte demandada, que

${ }^{69}$ Crítica fortemente elaborada em relação ao formalismo vem de Schopenhauer referindo que deve haver o desapego do formalismo por nãos nos apresentar grandes vantagens, vide: Schopenhauer, Arthur. Como vencer um debate sem precisar ter razão: em 38 estratagemas, trad. Daniela Caldas e Olavo de Carvalho, Rio de Janeiro: Topbooks, 1997, p. 21.

${ }^{70}$ Sobre a idéia de formalismo no processo civil, deve-se observar a obra do jurista Carlos Alberto Alvaro de Oliveira, que refere a importância do formalismo, na medida adequada, sendo este formalismo, para ser aceitável, valorativo e não um formalismo despropositado que afoga o Poder Judiciário e prejudica a sistemática processual. (OLIVEIRA, Carlos Alberto Alvaro. Do formalismo no processo civil, $2^{\circ}$ ed. rev. e ampli., São Paulo: Saraiva, 2003).

${ }^{71}$ Sobre esse princípio consultar BUENO, Cassio Scarpinella. Curso sistematizado de direito processual civil: teoria geral do direito processual civil: vol. 1, São Paulo: Saraiva, 2007, p. 107. - verbis "O núcleo essencial do princípio do contraditório compõe-se, de acordo com a doutrina tradicional, de um binômio: ciência e resistência ou informação e reação. O primeiro destes elementos é sempre indispensável; o segundo, eventual ou possível."; também observar NERY JÚNIOR, Nelson. Princípios do processo civil na constituição federal, $7^{\circ}$ ed. rev. atual., São Paulo: RT, 2002, p. 134;

RPGE, Porto Alegre, v. 33, n. 70, p. 87-124, 2012 


\section{2}

propiciará as diversas formas de resposta - a contestação, as exceções e a reconvenção - que o processo civil brasileiro elegeu como meios adequados para manifestação da parte ré. Assim também pode se dar no processo cautelar ou ainda na execução seja por titulo judicial (hoje chamado de cumprimento de sentença) - caso através da intimação - ou ainda por título extrajudicial - no caso seria citação para que a parte adversa se manifestasse.

Conexo a esse princípio do contraditório vem o princípio da ampla defesa ${ }^{72}$, que visa proporcionar as partes a ampla forma de defesa, possibilitando aos sujeitos processuais as diversas maneiras de se manifestar, tanto para o réu quanto para o autor. No caso do réu, por exemplo, que após receber a citação pode se defender através da contestação ou exceções e até mesmo reconvir. Já para o autor após essa manifestação da parte ré poderá replicar, rebatendo todas as argüições que foram efetivadas pela parte ré, utilizando também a idéia de ampla defesa.

Ademais, a ampla defesa esta também disposta, ainda no processo cognitivo, através dos diversos meios de prova que o Código de Processo Civil proporciona, desde o depoimento pessoal, que é efetivado pelas próprias partes em audiência, até a utilização de uma inspeção judicial que pode ser feita caso uma das partes tenham efetivado o pedido e o magistrado deferido. Tudo isso, sem falar na prova testemunhal que também é uma das formas que o Codex de Processo Civil nacional elegeu. Deve-se referir, por fim, com relação a esse princípio, que essa ampla forma de defesa pode ser obtida também no processo cautelar e no de execução, guardando as suas peculiaridades e forma de defesa, que, como se sabe, não são tão amplas como as do processo de conhecimento.

${ }_{72}$ BUENO, Cassio Scarpinella. Curso sistematizado de direito processual civil: teoria geral do direito processual civil: vol. 1, São Paulo: Saraiva, 2007, p. 112 e ss. 
Além desses princípios podemos referir também o princípio da razoável duração do processo ${ }^{73}$ como um dos princípios que dão base a idéia de democracia que pode ser obtida através do processo. Esse princípio está ligado ao da celeridade, que será tratado a posteriori, sendo o garantidor máximo da idéia de tempo ${ }^{74}$ adequado ao processo, sendo a válvula de escape para que o processo possa ser ao mesmo tempo célere e respeitador do devido processo legal.

O processo não pode ser moroso ${ }^{75}$ por demasia e muito menos célere ao ponto de suprimir garantias constitucionais e os direitos das partes. Assim, todo o processo deve durar aquilo que efetivamente seja o necessário para a correta solução da lide.

O princípio da celeridade $e^{76}$ que é um dos mais buscados em nossa sociedade deve ser interpretado da forma correta, para que injustiças não aconteçam. A celeridade em um mundo globalizado e rápido, onde as negociações se dão quase que de imediato, se faz necessária para a manutenção da realidade que a sociedade massificada de hoje vivencia.

73 Para averiguar essa noção de razoável duração do processo veja-se: CARVALHO,
Fabiano. EC n. 45: reafirmação da garantia da razoável duração do processo. In:
WAMBIER, Teresa Arruda Alvim et al. (Coord.). Reforma do judiciário: primeiros
ensaios críticos sobre a EC n. $45 / 2004$. São Paulo: Revista dos Tribuinais, 2005 ,
p.216. "Isso importa dizer que todos têm acesso à justiça para postular e obter uma
tutela jurisdicional adequada. Nesse contexto, a prestação da tutela jurisdicional em
tempo razoável garante o efetivo acesso à justiça, porquanto o direito à prestação
jurisdicional dentro de um tempo aceitável é uma exigência da tutela jurisdicional
efetiva". Observe-se também as palavras de MARINONI, Luiz Guilherme, Curso
de processo civil: Teoria geral do processo, v. 1 , São Paulo: RT, 2006 , p. 221 e ss.
74 Sobre a relação tempo e direito - no nosso casso processo - segundo o jurista
francês François deve-se tomar o devido cuidado para que as coisas não se
acelerem por demais, visto que o direito deve seguir o seu tempo normal, sem
uma aceleração exacerbada e desmotivada que prejudicaria e muito a natural
preservação de um direito em sua essência máxima. (OST, François. O tempo do
direito. Lisboa: Instituto Piaget, 1999 , p. 39 .)
75 A necessidade de pensar algo que possa agir contra a morosidade ou lentidão
dos processos, algo que está sendo perceptível, sobre a busca de soluções veja -
versão mais atual de - OST, François. O tempo do direito, Trad. Élcio ernandes,
Bauru: Edusc, 2005 , p. 17 ; também observar MARINONI, Luiz Guilherme, Curso
de processo civil: Teoria geral do processo, v. 1, São Paulo: RT, 2006, p. 186 e ss.
76 Sobre a conceituação deste princípio ver PORTANOVA, Rui. Princípios do
processo civil, $6^{\circ}$ ed., Porto Alegre: Livraria do Advogado, 2005 , p. 171 e ss. RPGE, Porto Alegre, v. 33, n. 70, p. 87-124, 2012 


\section{4}

A idéia de processo célere se implantou para que houvesse a superação do velho modelo processual formalista e lento, que instaurou a morosidade que parecia interminável e invencível, mas que a partir dessa oxigenação que se deu com Processo Civil, através da celeridade, muita coisa mudou, alterando-se inclusive a própria noção de tempo em relação ao processo.

Essa implementação da celeridade foi uma vitória que todos os processualistas devem comemorar. Mas, hodiernamente, a busca por celeridade se tornou desmedida e desenfreada, prejudicando-se direitos e até mesmo a própria noção de processo, que foi construída através de delongada experiência forense ao redor do mundo ${ }^{77}$.

Diversas alterações foram procedidas no modelo de processo existente até aquele momento, alterando-se o agravo ${ }^{78}$, a execução ${ }^{79}$, a forma de se contar os prazos ${ }^{80}$ e muito mais. Todas essas mudanças foram formuladas e projetadas sob o enfoque da celeridade processual. A intenção do legislador foi boa, sem, no entanto, atentar para a medida em que essa celeridade deveria estar posta, de forma que

\footnotetext{
${ }^{77}$ Ademais, deve-se observar que a celeridade nem sempre garante justiça, por vezes o que se dá é o contrario pois a celeridade, por sua natureza, gera injustiças pela ausência de tempo para solucionar a problemática, afastando a idéia da justiça cidadã, in SANTOS, Boaventura de Souza. Para uma revolução democrática da justiça, $2^{\circ}$ ed., São Paulo: Cortez, 2008, p. 24.

${ }_{78}$ Foi modificado pela Lei $11.187 / 2005$, fazendo com que a regra dos agravos passasse a ser o retido e não mais o de instrumento, que se dará somente em casos excepcionais, legislativamente falando, mas que na prática pouca coisa mudou.

${ }^{79}$ Nesse caso diga-se corretamente fase de cumprimento de sentença onde foram agregadas ao artigo 475 diversas letras, que vieram postados pela Lei 11.232/2005. ${ }^{80}$ Nesse caso a mudança se deu por conta da Lei 11.419/2006, quando se fala da informatização do processo, especificamente quando se fala da idéia de contagem do prazo, onde a partir da mudança conta-se a disponibilidade, depois a publicação e só então se inicia a contagem natural dos prazos, conforme o art. $4^{\circ}, \S 4$, vide: "Art. 4o Os tribunais poderão criar Diário da Justiça eletrônico, disponibilizado em sítio da rede mundial de computadores, para publicação de atos judiciais e administrativos próprios e dos órgãos a eles subordinados, bem como comunicações em geral.

$\S$ 4을 Os prazos processuais terão início no primeiro dia útil que seguir ao considerado como data da publicação."
} 
não viesse a prejudicar as partes e muito menos ao próprio Processo Civil brasileiro ${ }^{81}$.

Com tudo isso o que acabou por se dar, embora fosse boa a intenção do legislador ${ }^{82}$, foi a desestruturação do Processo Civil brasileiro, que hoje está representado por um Código extremamente recortado e desarmônico. Afora isso, relativamente a problemática da celeridade vejamos, por exemplo, o art. 285-A do Código de Processo Civil, que criou um "monstro" em favor da tão pretendida celeridade.

Segundo esse dispositivo poderá o juiz repetir o teor da sentença ${ }^{83}$ prolatada anteriormente, dispensando inclusive a citação da parte ré, desde que a questão em debate seja matéria exclusivamente de direito, devendo a sentença, exarada pelo mesmo juiz, ser de total improcedência. Essa é a "grande conquista" para muitos, mas que veridicamente nada possui de conquista, mas, sim, uma verdadeira desconstrução ${ }^{84}$.

Essa celeuma deve ser solvida a tempo, antes que muitos direitos sejam afetados e muitos cidadãos sofram de forma desmerecida em decorrência da celeridade processual desmedida.

${ }^{81}$ A intenção do legislador foi no sentido de desafogar o Poder Judiciário, o que
é efetivamente uma justa razão de implementação da celeridade - utilizou-se
inclusive das sumulas vinculantes -, devendo essa ser posta com cautela, nesse
sentido SANTOS, Boaventura de Souza. Para uma revolução democrática da
justiça, $2^{\circ}$ ed., São Paulo: Cortez, 2008, p. 25 .
82 Mas sabemos que embora tenha sido boa a intenção do legislador problemas
surgiram dessa pratica que o Legislativo no impôs, uma celeridade desmedida, que
ultrapassa o limite normal que é dado à celeridade, pois como se sabe a própria
celeridade tem um limite do qual não pode avançar, qual seja fazer injustiças, em
decorrência da célere corrida processual sem o devido cuidado com o processo
em tempo razoável e violador do devido processo legal. Idem., p. 27 .
83 Esse tipo de sentença incorrerá em ausência de "completeza" que é uma noção
sustentada por Taruffo in: TARUFFO. La testimonianza della parte nel sistema
dell'oralità, Giuffrè, 1974, p. 144 . Ademais, as sentenças devem ser fundamentadas
de forma precisa, e não com possuindo uma falsa fundamnetanção, pois o
magistrado deve convencer as partes de que sua decisão guarda uma lógica jurídica
correta, nesse diapasão vide: TARUFFO. Senso comune, esperienza e scienza nel
ragionamento del giudice, in revista trimestrale di diritto e procedura civile, Giuffrè,
p. 675,2001 , trad. Candido Rangel Dinamarco.
84 Aqui merece lembrança a ponderação de Boaventura, quando aduz que a
celeridade desmedida influencia claramente na qualidade das sentenças, que
passam, efetivamente, a se afastar dos critérios da qualidade da prestação
jurisdicional. (SANTOS, Boaventura de Souza. Para uma revolução democrática
da justiça, $2^{\circ}$ ed., São Paulo: Cortez, 2008 , p. 81 .)

RPGE, Porto Alegre, v. 33, n. 70, p. 87-124, 2012 


\title{
116
}

O dispositivo, ora comentado, é problemático assim como refere Nelson Nery Júnior ${ }^{85}$, - pendendo de solução inclusive frente ao Supremo Tribunal Federal através da ADI 3.695/DF - pois, em busca da celeridade, rompe com diversos princípios de índole constitucional, especificamente o do contraditório ${ }^{86}$, ampla defesa ${ }^{87}$, economia processual $^{88}$ e até mesmo à idéia de devido processo legal ${ }^{89}$.

\begin{abstract}
${ }^{85}$ NERY JÚNIOR, Nelson [et. all.]. Código de processo civil comentado e legislação extravagante, $10^{\circ}$ ed. rev., ampli. e atual., São Paulo: RT, 2007, p. 554-555.

${ }^{86}$ Em decorrência da ausência de possibilidade de conhecimento da demanda à parte contraria que tem o direito de saber que está sendo demandada, podendo conhecer, inclusive, a fundamentação da parte adversa para o pleito pretendido. Ademais, a violação é também frontal ao direito do autor de poder conhecer as razões da parte adversária sobre a temática que seria discutida, o que também poderia mudar totalmente o curso da lide.

${ }^{87}$ Esse princípio também é naturalmente violado, em decorrência da ausência de possibilidade de a parte ré se defender das pretensões da parte autora, retirando-lhe inclusive a possibilidade de reconvir, que seria extremamente útil para o réu que é demandado de forma equivocada. Dê-se o exemplo de um escritório de advocacia que sempre foi pontuado na demanda de seu cliente, e este após o termino da demanda, inconformado com a decisão que não lhe concedeu o que buscava vem a difamar a imagem do escritório e a mover uma ação judicial com o intuito de obter frente ao patrono uma indenização, se o patrono não tivesse a possibilidade de saber dessas condutas do seu antigo cliente, o que se daria através da ação, seria cerceado o direito de reconvenção que detém o dito escritório. Tudo isso é efetivamente complexo. Ademais, a própria parte autora não poderia utilizar as diversas formas de comprovação de seu direito em decorrência da utilização do art. 285-A, violador da ampla forma de defesa que ambas as partes teriam no processo. ${ }^{88}$ Esse dispositivo relatado também viola a economia processual, em decorrência da necessidade de intromissão do Tribunal de Justiça do respectivo Estado, em decorrência da sentença exarada que se reformada fará com que seja ordenada a citação da parte ré para que o processo tenha o seu curso natural, o qual deveria ser mantido, mas que em decorrência da aplicação do referido artigo obriga a parte a recorrer ao Tribunal de Justiça através de uma apelação para que possa se modificar a situação, isso se o próprio Tribunal modificar a sentença. Não sendo feito isso, a parte autora terá que se socorrer do Superior Tribunal de Justiça ou até mesmo do Supremo Tribunal federal, o que é um absurdo. Vejamos, o tamanho da problemática que esse artigo poderá trazer, movimentado, antes do momento adequando, toda uma estrutura do Judiciário, fazendo a questão chegar aos Tribunais para que possa, pelo menos, ser discutida depois em primeiro grau a questio, tornando o processo ainda mais lento, pois se obrigará a parte a ir ao Tribunais, sejam inferiores ou superiores, para conseguir que a parte adversária seja citada. Isso sim é um absurdo fenomenal, que destrói a idéia de celeridade e que de quebra ainda macula até mesmo um direito evidente que a parte tenha, somente em decorrência de um preciosismo processual infundado.

${ }^{89}$ Com a aplicação deste artigo 285-A, como querem alguns, será ainda violada a noção de devido processo legal, pois o processo perderá a sua simetria de atos logicamente concatenados, para pular uma fase, chegando ao ponto de ir aos
\end{abstract}


Não bastassem essas violações de índole principiológica, que estão tanto no viés constitucional como processual, ainda existiria a violação ao direito processual ${ }^{90}$, especificamente em relação à formação daquilo que chamamos processo, pois para que esse se forme deve haver a formação triangular, onde a parte autora demanda frente a ré repassando a sua inconformidade ao Juiz que propiciará ao réu o conhecimento da demanda existente em seu desfavor formando a chamada angularização processual ${ }^{91}$ que envolve as três partes ora referidas ${ }^{92}$.

Mais uma vez o tal dispositivo é prejudicial, agora atacando toda a teoria existente sobre o processo, que foi construída através da experiência de diversos juristas renomados, desconstruindo tudo aquilo que o direito processual civil praticava até então. A questão que surge é, vale realmente apena esse dispositivo? Será efetivamente célere?

Este autor crê que as respostas sejam negativas, mas fica no aguardo de novas discussões para que se possa chegar a um de-

Tribunais, para que depois de reformada a sentença ou até mesmo o acórdão, venhamos a regressar ao processo cognitivo para que o juiz ordene a citação da parte adversária, para só então continuar a seguir os caminhos processuais necessários para a obtenção de uma sentença robusta e bem fundamentada, que se obterá pelo livre convencimento motivado advindo das provas.

${ }^{90}$ Belíssimo estudo sobre a tutela processual foi construído pelo douto jurista Argentino Roberto Omar Berizonce, in: BERIZONCE, Roberto Omar. As garantias do cidadão na justiça, coord. Sálvio de Figueiredo Teixeira, São Paulo: Saraiva, 1993, p.123 e ss.

${ }^{91}$ Nesse sentido Nelson Nery Júnior é claro aduzindo que a citação é requisito de existência do processo, sem a qual não existirá litígio instaurado, pois sequer tomou ciência disto a parte ré, maculando-se a noção de processo que depende da participação de todos - autor, réu e juiz - para que seja existente a relação jurídica processual. NERY JÚNIOR, Nelson [et. all.]. Código de processo civil comentado e legislação extravagante, $10^{\circ}$ ed. rev., ampli. e atual., São Paulo: RT, 2007, p. 555. ${ }_{92}$ Cabe referir que hoje se fala muito na idéia da circularidade, na qual não observaremos mais a relação processual como um triangulo em que autor e réu estão colocados abaixo do Juiz, mas sim uma relação processual desenvolvida em forma de circulo no qual autor, réu e juiz estão postados em um circulo de forma igualitária. Nessa esteira de raciocínio vejamos: LUHMANN, Niklas. Sociologia do Direito I, Tradução de Gustavo Bayer, Rio de Janeiro: Tempo Brasileiro, 1985, p. 115 e 121; TEUBNER, Gunther. O direito como um sistema autopoiético, Lisboa: Fundação Calouste Gulbenkian. 1989. p. 53; ZYMLER, Benjamim. Política e Direito: uma visão autopoiética, Curitiba: Juruá, 2002, p.65; e por fim observemos ROCHA, Leonel Severo; SCHWARTZ, Germano; CLAM, Jean. Introdução à Teoria do Sistema Autopoiético do Direito,. Porto Alegre: Livraria do Advogado, 2005, p. 38.

RPGE, Porto Alegre, v. 33, n. 70, p. 87-124, 2012 


\section{8}

nominador razoável e que se possam buscar o melhor tanto para o processo, como ciência ou ainda técnica ${ }^{93}$, como para a parte que busca a realização fenomênica de seu direito.

Todos esses princípios analisados em conjunto podem fazer com que outro princípio seja adimplido, o princípio da efetividade ${ }^{94}$ da prestação da tutela jurisdicional ${ }^{95}$, onde a prestação da tutela que é efetivada pelo Poder Judiciário ${ }^{96}$ deve obter os melhores resultados possíveis, dotando de solução adequada a problemática que foi discutida na lide, sendo sempre uma prestação real, fundamentada e que dure o tempo necessário para a sua produção, sem, no entanto, ser morosa.

Com toda essa aplicação principiológica ao processo, que vem de origem nobre qual seja a Constituição, aliada a todas as praticas participativas que o processo possibilita, somando-se à receptividade do Poder Judiciário - não mantendo o Judiciário como a mera boca da Lei ${ }^{97}$ - que sempre se mostrou disposto a ouvir o cidadão,

${ }^{33} \mathrm{O}$ processo, como técnica da formulação das normas jurídicas e de efetivação do direito conserva, e necessariamente deveria fazê-lo, as conotações políticas e econômicas que conformam o próprio direito a que ele se vincula, instrumentalmente. In PASSOS, José Joaquim Calmon de. Participação e processo coord. Ada Pellegrini Grinover, São Paulo: RT, 1988, p. 86.

${ }_{94}^{4}$ Uma obra excelente foi construída pelo jurista gaúcho Darci Ribeiro, quando em seus estudos doutorais, sendo uma análise pontuada e que passou também pela idéia de tutela judicial efetiva, que é aquilo que muito se busca em nossa comunidade jurídica. In: RIBEIRO, Darci Guimarães. La pretensión procesal y La tutela judicial efectiva, Barcelona: J.M.Bosch editor, 2004, p. 75 e ss. Também observar a lições de BEDAQUE, José Roberto dos Santos. Efetividade do processo e técnica processual, $2^{\circ}$ ed., São Paulo: Malheiros, 2007, p. 49 e ss. Também sobre a efetividade pode ser consultado MARINONI, Luiz Guilherme, Curso de processo civil: Teoria geral do processo, v. 1, São Paulo: RT, 2006, p. 215 e ss.

${ }^{95} \mathrm{~A}$ prestação da tutela jurisdicional deve ser de qualidade, devendo o judiciário está preocupado em qualificar as suas decisões, devendo essas sofrerem o devido controle e os magistrados uma maior responsabilização por suas decisões, não sendo os magistrados a mera boca da lei. In BERIZONCE, Roberto Omar. Participação e processo coord. Ada Pellegrini Grinover, São Paulo: RT, 1988, p. 136-138.

${ }^{96}$ Berizonce ainda refere que os Poder Judiciário deve ser responsabilizado não somente pelos erros judiciais, de forma objetiva, mas também pelo "funcionamento anormal" e de "falta de serviço" que resultam em frustração à garantia do devido processo legal. Idem., 142.

${ }^{97}$ CHIOVENDA, Giuseppe. Principios del derecho procesal, Madri: Reus, s/d, p. 365. 
poderemos contribuir para a efetiva aplicação da democracia em nosso país, deixando de ser um sonho, um objetivou ou ainda uma ilusão, passando a ser algo real e alcançável, beneficiando a todos os membros de um país que clama pelo respeito aos direitos fundamentais e que labuta diariamente pela obtenção da justiça!

\section{CONSIDERAÇÕES FINAIS}

Realmente vivenciar a democracia, em nosso país, se tornou algo difícil e também incomum, tudo isso em decorrência dos diversos desmandos e práticas de nossos representantes, que deveriam agir na conformidade daquilo que a própria Constituição Federal prevê o que seja um país que preze pela justiça e pela democracia.

Em verdade, a democracia ainda pode ser implantada em nosso país, não que seja algo fácil, mas que pelo menos é possível, desde que comecemos a atribuir essa função de busca da verdade e da justiça ao Judiciário, que com o seu cuidado e com sua imparcialidade natural poderá promover uma participação efetiva e real de muitos dos cidadãos.

O meio próprio para que o Poder Judiciário consiga completar essa "missão impossível" passa pela franca utilização do Processo Civil, como realizador da participatividade que se dá através das diversas opções de manifestação jurídico-processuais existentes, que garantem ao cidadão o livre acesso ao que pretendem.

Essa democracia que poderá ser construída necessita de um "avalista" de respeito, que seja capaz de agir sem temer e que possa ser acima de tudo imparcial, requisitos que se acham posto no Poder Judiciário.

Esse poder só pode agir através do processo, meio eleito pelo legislador e pelos doutrinadores como correto para que todos possam ter acesso franco ao Estado Judiciário. Assim, não há como buscar democracia sem pensar em Processo Civil, sendo o meio propiciador de todo o tipo de manifestação e participação, onde o cidadão será ouvido sempre sem ser unicamente quando da época das eleições ou ainda de um plebiscito ou referendo.

Portanto, falar em democracia nos leva a falar em Direito Processual Civil, um processo formal, mas de formalidades que sejam 
valorativas e não meramente impeditivas de efetividade. Pensar em democracia, por assim dizer, fará ligação com a noção de Processo cooperativo, onde as partes colaborarão ao máximo para a obtenção da verdade real e formal, que poderá repassar aos demandantes o mínimo critério de justiça e democracia.

\section{REFERÊNCIAS}

ALEXY, Robert. Teoria dos direitos fundamentais, trad. Virgilio Afonso da Silva, São Paulo: Malheiros, 2008.

AMARAL, Roberto. A democracia representativa está morta; viva a democracia participativa. In: Direito Constitucional. Estudos em homenagem a Paulo Bonavides, São Paulo: Malheiros, 2003.

BAUMAN, Zygmunt. Modernidade e Ambivalência, Rio de Janiro: Jorge Zahar Editor, 1999.

BEDAQUE, José Roberto dos Santos. Efetividade do processo e técnica processual, $2^{\circ}$ ed., São Paulo: Malheiros, 2007.

BERIZONCE, Roberto Omar. As garantias do cidadão na justiça, coord. Sálvio de Figueiredo Teixeira, São Paulo: Saraiva, 1993.

BOBIO, Norberto. Teoria do ordenamento jurídico, trad. Maria Celeste Cordeiro Leite dos Santos, $10^{\circ}$ ed., Brasília: Editora Universidade de Brasília, 1999.

BUENO, Cassio Scarpinella. Curso sistematizado de direito processual civil: teoria geral do direito processual civil: vol. 1, São Paulo: Saraiva, 2007.

CAMPBELL, C. The Romantic Ethic and the Spirit of Modern Consumerism, Oxford: Blackwell, 1987.

CANOTILHO, José Joaquim Gomes. Estudos sobre direitos fundamentais, $2^{\circ}$ ed., Portugal: Coimbra Editora, 2008.

CANOTILHO, José Joaquim Gomes. Direito Constitucional e Teoria da Constituição, 7º, ed., Coimbra: Almedina, 2003.

CARRIÓ, Genaro R. e CARRIÓ, Alejandro D. El recurso extraordinario por sentencia arbitrria, Buenos Aires, Abeledo-perrot, 1983. 
CARVALHO, Fabiano. EC n. 45: reafirmação da garantia da razoável duração do processo. In: WAMBIER, Teresa Arruda Alvim et al. (Coord.). Reforma do judiciário: primeiros ensaios críticos sobre a EC n. 45/2004. São Paulo: RT, 2005.

CHIOVENDA, Giuseppe. Principios del derecho procesal, Madri: Reus, s/d.

DELACAMPAGNE, C. História da Filosofia no Século XX, Rio de Janeiro: Jorge Zahar Editor, 1995.

DELGADO, José Augusto. As garantias do cidadão na justiça, coord. Sálvio de Figueiredo Teixeira, São Paulo: Saraiva, 1993.

DINAMARCO, Cândido Rangel. Participação e processo coord. Ada Pellegrini Grinover, São Paulo: RT, 1988.

DURIGUETTO, Maria Lúcia. Sociedade civil e democracia - Um debate necessário. São Paulo: Cortez, 2007.

DWORKIN, Ronald. Levando os direitos a sério, trad. Nelson Boeira, São Paulo: Martins Fontes, 2002.

FEATHERSTONE. Cultura de consumo e Pós-modernismo, São Paulo: Studio Nobel, SESC, 1995.

GADAMER, Hans-Georg. Verdade e método II, trad. Enio Paulo Gianchini e Maria Sá Cavalcante Schuback, Petrópolis: Vozes, 2002. GARAPON, Antonie. Bem julgar: ensaio sobre o ritual judiciário, Lisboa: Instituto Piaget, 1997.

GIDDENS. "A vida em uma sociedade pós-tradicional", In: BECK, GIDDENS \& LASH, 1997.

HARVEY, David. Condição pós-moderna, São Paulo: Edições Loyola, 1992.

HELLER, Agnes. Mas allá de la justicia, Barcelona: Editorial Crítica, versão espanhola de 1990.

JAYME, Erik. Cours général de droit intenacional prive, In recueil des cours, Académie de droit intenacional, t, 251, 1997.

KELSEN, Hans. Teoria pura do direito, $4^{\circ}$ Ed., São Paulo: Martins Fontes, 1994. 


\section{2}

KUMAR, Krishan. Da sociedade pós-industrial à pós-moderna, Rio de Janiro: Jorge Zahar Editor, 1997.

LYOTARD, Jean-François. O pós-moderno, Rio de Janeiro: Olympio Editora, 1986.

LOPES, José Reinaldo de Lima, in: FARIA, José Eduardo(coord.) [et. all]. Direito e justiça: A função social do judiciário, São Paulo: Ática, 1989.

LUHMANN, Niklas. Sitemi sociali: Fondamenti di una teoria generale, Bolonha:Il Mulino, 1990.

LUHMANN, Niklas. Sociologia do Direito I, Tradução de Gustavo Bayer, Rio de Janeiro: Tempo Brasileiro, 1985.

MARINONI, Luiz Guilherme [et. all.]. Código de direito processual civil comentado, São Paulo: RT, 2008.

MARINONI, Luiz Guilherme, Curso de processo civil: Teoria geral do processo, v. 1, São Paulo: RT, 2006.

MARQUES, Claudia Lima. Contratos no código de defesa do consumidor: o novo regime das relações contratuais, 4. ed. rev., atual. e ampli., incluindo mais de 1.000 decisões jurisprudenciais. São Paulo, RT, 2002.

MITIDIERO, Daniel. Colaboração no processo civil: pressupostos sociais, lógicos e éticos, São Paulo: RT, 2009.

NERY JÚNIOR, Nelson. Princípios do processo civil na Constituição Federal, $7^{\circ}$ ed., São Paulo: RT, 2002.

NERY JÚNIOR, Nelson [et. all.]. Código de processo civil comentado e legislação extravagante, $10^{\circ}$ ed. rev., ampli. e atual., São Paulo: RT, 2007.

NEVES, Antônio Castanheira. O direito hoje em com que sentido? Lisboa: Editora Piaget, 2002.

NEVES, Antônio Castanheira. O instituto dos "assentos" e a função jurídica dos tribunais supremos, Coimbra, 1983.

OLIVEIRA, Carlos Alberto Alvaro. Do formalismo no processo civil, $2^{\circ}$ ed., rev. e ampli., São Paulo: Saraiva, 2003. 
OST, François. O tempo do direito. Lisboa: Instituto Piaget, 1999.

PASSOS, José Joaquim Calmon de. Participação e processo coord. Ada Pellegrini Grinover, São Paulo: RT, 1988.

PERELMAN, Chaim. Ética e direito, São Paulo: Martins Fontes, 1996.

PICORDI, Nicola. La vocazione del nostro tempo per la giurisdizione, revista trimestral de Diritto Procedura Civile, Giuffrè, 2004.

PISANI, Andrea Proto. Revista da Escola da Magistratura do Rio de Janeiro, n. 16, 2001.

PORTANOVA, Rui. Princípios do processo civil, $6^{\circ}$ ed., Porto Alegre: Livraria do Advogado, 2005.

PRZEWORSKY, Adam. Estado e Economia no Capitalismo. Trad. Argelina C. Figueiredo, Pedro Paulo Z. Bastos. Rio de Janeiro: Relume Dumará, 1995.

RIBEIRO, Darci Guimarães. La pretensión procesal y La tutela judicial efectiva, Barcelona: J.M.Bosch editor, 2004.

ROCCO, Ugo. Trattato di diritto processuale civile V. I, $2^{\circ}$ ed., Torino: Topografia Sociale Torinese, 1966.

ROCHA, Álvaro Felipe Oxley da. Sociologia do direito: A magistratura no espelho, São Leopoldo: Editora UNISINOS, 2002.

ROCHA, Leonel Severo; SCHWARTZ, Germano; CLAM, Jean. Introdução à Teoria do Sistema Autopoiético do Direito,. Porto Alegre: Livraria do Advogado, 2005.

ROUANET, S. P. As razões do iluminismo, São Paulo: Companhia das Letras, 1987.

SANTOS, Boaventura de Souza. Para uma revolução democrática da justiça, $2^{\circ}$ ed., São Paulo: Cortez, 2008.

SANTOS, Boaventura de Souza. Pela Mão de Alice: O social e o político na pós-modernidade, São Paulo: Cortez, 1997.

SANTOS, Moacyr Amaral. Primeiras linhas de direito processual civil, $7^{\circ}$ ed., São Paulo: Saraiva, 1980. 


\section{4}

SARLET, Ingo Wolfgang. Dignidade da Pessoa Humana e Direitos Fundamentais na Constituição Federal de 1988, Porto Alegre: Livraria do advogado, 2001.

SCHOPENHAUER, Arthur. A arte de escrever, trad. Pedro Sussekind, Porto Alegre: L\&PM, 2008.

SCHOPENHAUER, Arthur. Como vencer um debate sem precisar ter razão: em 38 estratagemas, trad. Daniela Caldas e Olavo de Carvalho, Rio de Janeiro: Topbooks, 1997.

SILVA, Ovídio A. Baptista da. As garantias do cidadão na justiça, coord. Sálvio de Figueiredo Teixeira, São Paulo: Saraiva, 1993.

SILVA, Ovídio A. Baptista da. Democracia e sociedade de massa www.Baptistadasilva.com.br/artigos.

SILVA, Ovídio A. Baptista da. Jurisdição, direito material e processo, Forense, 2007.

SILVA, Ovídio A. Baptista da. In: Participação e processo, coord., Ada Pellegrini Grinover, São Paulo: RT, 1988.

SILVA, José Afonso da. Curso de Direito Constitucional Positivo, $15^{\circ}$ ed., rev. e atual., São Paulo: Malheiros, 1998.

TEIXEIRA, Sálvio de Figueiredo. As garantias do cidadão na justiça, coord. Sálvio de Figueiredo Teixeira, São Paulo: Saraiva, 1993.

TEUBNER, Gunther. O direito como um sistema autopoiético, Lisboa: Fundação Calouste Gulbenkian. 1989.

TOCQUEVILLE, Alexis de. La démocratie em Amérique, Paris: Garnier: Flammarion, 1951, t. II.

TARUFFO. La testimonianza della parte nel sistema dell'oralità, Giuffrè, 1974.

TARUFFO. Senso comune, esperienza e scienza nel ragionamento del giudice, in revista trimestrale di diritto e procedura civile, trad. Cândido Rangel Dinamarco, Giuffrè, 2001.

VATTIMO, Gianni. O Fim da Modernidade: niilismo e hermenêutica na cultura pós-moderna, Lisboa: Editorial Presença, 1987.

ZYMLER, Benjamim. Política e Direito: uma visão autopoiética, Curitiba: Juruá, 2002. 